\title{
Is the Eurozone Rescue Strategy Tantamount to the Rearrangement of the Deckchairs on the Titanic?
}

\author{
Miroslav N. Jovanović \\ University of Geneva
}

\begin{abstract}
The eurozone is the crown jewel in the process of European integration. This monetary zone includes the most advanced integration grouping of countries in the European Union. The eurozone has been expanding the number of its participants, a sign of success in any economic or political union. Politicians promised citizens stability and perpetual economic progress at the time of the eurozone inauguration (1999). This monetary integration has been a predominantly political process which neglected certain economic fundamentals for long term durability. These include federal-type intra-group fund transfers and orientation towards economic growth. Certain eurozone flaws appeared, raising powerful doubts about its survival. Some of the internal troubles of the eurozone such as an endemic lack of respect of rules, were amplified by the global credit crunch, bringing into question the initial promises made to citizens. A series of rescue operations commenced in 2010. Too much political and economic capital has been invested in the eurozone, to the extent that its statesmen will do everything they can to rescue it. If its participants believe the deal to be beneficial, the eurozone will continue its existence, but several federal-type amendments are necessary. Otherwise, the eurozone may join the ranks of a series of European monetary zones that have disintegrated over the past two centuries. The bloc's citizens (and others) are unwitting observers of a slow motion eurozone train crash. Even though the eurozone burdens some of its member countries with high costs, its break-up or countries' departure from it may prove even worse, but not inconceivable.
\end{abstract}

\footnotetext{
*Corresponding address: Miroslav N. Jovanović ; European Institute, University of Geneva, rue Daniel Colladon 2, 1204 Geneva, Switzerland, Tel: +41229172493, E-mail: miroslav.jovanovic@unige.ch. 
- JEL Classification: F31, F33, F36

- Keywords: EMU, Eurozone, Rescue, Bailout, Break Up, Deficit, Debt, Bond, Germany, France, Greece

\section{Introduction}

The eurozone and its currency, the euro, celebrated their tenth anniversary in 2009. Eurozone enthusiasts were delighted about the event, which represented another step towards the federal future of Europe. Membership of the bloc grew from 11 in 1999 to 17 in 2011, a clear sign of success. The eurozone's sceptics argued that the greatest achievement was that the euro survived this period, while the essentialists, looking for the root causes and evolution of ideas and events, were trying to find inspiration for the way that would lead the eurozone towards its $20^{\text {th }}$ anniversary.

The objective of this article is to contribute to analyses of the past attainments of the eurozone, as well as to diagnose the challenges and traps it may encounter on the road towards its $20^{\text {th }}$ anniversary. The article is structured as follows. After this introduction comes a summary of the basic features of the eurozone. Section III gives statistics on debt and deficit, while section IV briefly considers conflicting theoretical deficit-reduction approaches. The expansion or break up of the eurozone is tackled in section V. Specific eurozone country crises are presented in section VI. Section VII looks at muddling through crises with no long-term sustainable solution in sight, and the conclusion (section VIII) deals with the notion that so much capital, political and otherwise, has been invested in the eurozone that its politicians would do their utmost to save it. Should this be the case, it will be quite a job as long-term austerity with little or no growth will be resisted by the people.

\section{Background}

Monetary integration is the area where the most robust and real economic integration is tested. If the objective of the integrated countries is to solidify their deepest economic (and other) integration intentions and objectives, then the monetary integration is a necessary step to make those objectives irrevocably credible. 
Economic theory suggests that, in general, the economic and monetary union $(\mathrm{EMU})^{1}$ ought to be based on the following essentials:

- centralised monetary policy

- single central bank (or their system)

- currency convertibility (at least internal)

- unified performance on currency markets

- capital market integration (including a common government/group treasury bond)

- identical/similar rate of inflation

- fiscal systems harmonisation

- semi-automatic fiscal transfers to disadvantaged regions as balance of payments disequilibria are replaced by regional disequilibria

- free factor mobility

- coordination of economic policies ${ }^{2}$

The EMU has both its costs and benefits. Economic and political costs include losses such as: the sovereign right to print own money (seigniorage), the possibility to choose freely the national relation between inflation and unemployment, devaluation, the technical and administrative costs of switching to the new currency. Denied the possibility to devalue its own national currency, the external market pressure on a country is translated into interest differentials on government bonds between the stable core EMU countries and those of (unstable) countries on the periphery of economic activity. In short, currency risk is replaced by credit risk.

The EMU has important and attractive benefits. They include: no exchange risk and volatility (a key advantage of the common currency); the pooling and reduction of national reserves against exchange-rate crises; the transparency and direct comparability of prices (competition is improved); reduction in transaction costs; improved integration of markets; cheaper finance for businesses; improved investment decisions and higher returns bring gains from additional trade; and the potential for improved macroeconomic policy for countries with weak credentials

\footnotetext{
${ }^{1}$ In a monetary system, countries link their currencies. In a monetary union, countries irrevocably fix their currencies (de iure EMU) or introduce a single currency (de facto EMU).

${ }^{2}$ Markets may be integrated among the countries without monetary integration as is the case in the European Free Trade Association (EFTA); monetary integration may exist even though the markets are not integrated as is the case in the West African Monetary Union (WAMU); and the single currency may be circulating in the countries which are not formally integrated. Andorra, Monaco, Montenegro, San Marino and Vatican use the euro as the national legal tender even though they are not in the EU.
} 
in this matter. These potential EMU-related gains may be clear to economists. The problem is, however, whether the non-economists can comprehend it.

The European Union (EU) established a free internal market for goods, services and factors - the Single European Market - in 1993. In such an integrated group, internal trade/investment flows and competition may be in jeopardy because of fluctuation in rates of exchange. To eliminate that risk, a kind of a monetary integration may be necessary. That is one of the reasons for monetary integration and the creation of the eurozone in the EU in 1999. Aside from this economic rationale, there was another strong and decisive political reason for monetary integration. It was the French anxiety following the reunification of Germany in 1990. France wanted to 'lock' the reunified Germany deeply into the European project for a longer period of time in the future. Hence came the Maastricht Treaty (1992), which basically concerned about the creation of the EMU in the EU. Such projects usually take place in groups that are on the way towards federal unification.

The publicly presented rationale for the EMU included arguments such as enhanced monetary stability, increased competition, reduced transaction costs, access to a wider and deeper market, improved allocation of resources, and increased gains both from economies of scale and from trade. The European Central Bank (ECB) was established as the glorified EU version of the German Bundesbank. The ECB was charged with keeping prices stable, defining and implementing monetary policy, conducting foreign exchange operations, holding and managing reserves, as well as promoting smooth payments.

The EMU entry terms were set by politicians. The conditions were that the candidate country must have stable prices (low inflation), the budget deficit must be up to 3 per cent of GDP, national debt must be no bigger than 60 per cent of GDP, the currency must not be devaluated for at least two years and long-term interest rates must be in line with the best performing EU member countries. These conditions had in mind a strong monetary (and economic) convergence of the countries that would be permitted to join the eurozone in 1999. However, there was also a political compromise and a loophole. If a country (Belgium, Italy and latter Greece) does not satisfy these conditions, but if it makes serious and obvious efforts to achieve them, it may be permitted to join the eurozone.

The eurozone started out as $11 \mathrm{EU}$ member states in 1999, and the new currency, the euro as the eurozone $\ddot{u} b e r$-currency, started circulation in $2002 .{ }^{3}$ It

\footnotetext{
${ }^{3}$ Austria, Belgium, Finland, France, Germany, Ireland, Italy, Luxembourg, the Netherlands, Portugal and Spain. Greece was let to join the Eurozone in 2001.
} 
was the most ambitious project in Europe since the Bolshevik Revolution (1918). No currency has circulated in Europe so widely since the Roman Empire. The introduction of the euro in January 1999 was the biggest currency innovation since the introduction of the United States (US) dollar in 1792. In general, the conditions set for the eurozone were a political decision/compromise with little regard for the suggestions/conditions that came from economic theory. ${ }^{4}$ Hence, theory, in this case, did not correctly represent the real world (de Grauwe, 2006, p. 711).

The eurozone had a political logic, but its economic construction was flawed from the outset. It was a project constructed for fair weather as no life rafts were put on board. The project attempted to have one monetary policy and, at the same time, it had separate fiscal policies in the eurozone's member countries. The result was profligate expenditure policies in the countries with weak stability culture that profited from the high credibility (i.e. lower interest rates) of the common currency. Once in trouble, countries could not counter financial difficulties on their own (devaluate).

Compared with another monetary union such as the one in the US, the eurozone lacks wage flexibility, labour mobility, a flexible labour market (easier firing), semi-automatic fiscal transfers and built-in stabilisers. These are also pointers towards economic theory that the eurozone founding fathers neglected. Fiscal transfers are, however, a delicate and thorny affair. Recall problems which exist even within a single state, such as in Belgium (Flanders and Wallonia) or north and south Italy.

While eurozone monetary affairs were centralised, public and private expenditure was in the national domain. The objective of the Stability and Growth Pact (1997) was to keep the eurozone on track by means of a sustainable fiscal policy. To put it bluntly, Germany mistrusted Italy in fiscal (and monetary) affairs. The Pact limits a eurozone member country's deficit to 3 per cent of GDP and threatens with relatively heavy fines any member country that exceeds this annual limit. Germany wanted to have automatic fines imposed on any eurozone country with a budget deficit of over 3 per cent. However, France argued that sanctions for excessive borrowing by member states must be a political matter. The final agreement was that the Council of Ministers (excluding the country being hit) may penalise the country with a fine of up to 0.5 per cent of its GDP by a qualified majority vote. Countries in deep recession are exempt from a fine, with the proviso

${ }^{4}$ The interested reader is invited to consult Praussello (2011) on this point. 
that their economies shrink by more than 2 per cent within a year. ${ }^{5}$

The European Commission issued its first warning to a eurozone country on 30 January 2003. This was to Germany, the biggest European economy and, ironically, the country that insisted on the introduction of the Pact. Subsequently, the Commission also issued warnings to France, Italy, Greece and Portugal. While Germany and Portugal made rigorous spending cuts in order to try to reduce their budget deficit below 3 per cent in 2004, France did not do so as it was facing falling government revenue and rising unemployment. The European Commission's president, Romano Prodi, told Le Monde (17 October 2002): 'I know very well that the Stability Pact is stupid, like all decisions that are rigid. The Stability Pact is imperfect, we need a more intelligent mechanism and more flexibility'. This gave certain hints that the European Commission may yield to the demands of the big countries (Germany, France and Italy which together account for three-quarters of the eurozone economy), even though the (small) countries that have taken unpopular and strict macroeconomic measures were reluctant to give Germany and France a 'get out of jail free' card.

Most of these deficits arose because of cyclical factors (growth rates were lower than expected), rather than because of reckless national spending. Hence, revenues were falling and were not meeting the budgetary outlays. This means that the 3 per cent limit could be breached (with impunity) for many years in a row. This is adding to the strain visible in the Stability and Growth Pact. Is a solution to the problem to relax the 3 per cent limit? Would this introduce a precedent: when the rules governing the eurozone become inconvenient, should they be rewritten? Would this put at risk the credibility of the eurozone? Eurozone finance ministers (ECOFIN) breached the Stability and Growth Pact in November 2003 by voting not to impose sanctions on France and Germany for continually breaking the 3 per cent deficit cap. France and Germany avoided the rules without incurring any penalty. The eurozone, therefore, turned into a two-tier group in which one set of rules apply for big countries and another set for the small ones.

The flaw of the Stability and Growth Pact has always been that it did not consider the economic cycle, intra-EU capital flows and, more than anything, different and context-specific situation in each eurozone country. Its application

\footnotetext{
${ }^{5} \mathrm{~A}$ year is a phenomenon in astronomy. Annually balanced budgets had certain justification when the economy was based primarily on agricultural production. Revenue and spending had rather regular annual cycle. The structure of the economy has changed. Budgets may be set on different grounds, not necessarily on astronomy and/or farm-related biological cycle.
} 
was, however, more theoretical rather than practical. This became obvious during and after the Global Credit Crunch 2007-09. ${ }^{6}$ During the deepest recession since 1929 governments had to spend more. The scope of the Pact's provisions (law) was preventing that.

One of the principal lessons from the Great Depression during the 1930s was that the governments should not try to balance budgets. Circumstances during the Global Credit Crunch were exceptional, so that the governments' 'emergency measures to rescue the banking sector over the past year have been so far-reaching that the EU's competition rules have been in effect suspended. ... the recession is testing the single European market to its limits. Governments are being tempted into defending narrow national interests at the expense of the common European good. ${ }^{7}$ The national stimulation packages and 'buy domestic' campaigns in 2009 were both against the law and the spirit of European integration. Even though EU governments committed $€ 3$ trillion for bank bailouts, the competition Commissioner, Neelie Kroes, stated that 'despite these aids, EU state aid rules had been respected all along, 8

The existing Stability Pact (with vague penalties) was breached 60 times $^{9}$ in a decade by many countries, including by the eurozone leaders, Germany and France. Partner states do not like to punish each other. They were horse-trading. In return for getting off scot free on their deficits, some states gave concessions to the others elsewhere in the EU affairs. One of the architects of the eurozone, Jacques Delors, said that 'It was a fault in the execution, not of the architects'. ${ }^{10}$

\section{Deficits and Debts}

The limit for public spending has been set in EU law for the countries that are in the eurozone and for the ones that strive to join: deficit is limited to 3 per cent of the GDP and debt to 60 per cent. Table 1 contains a snapshot of the deficits in select eurozone and other countries for the period 2006-13. The first observation is

\footnotetext{
${ }^{6}$ The Global Credit Crunch 2007-09 was instigated by the American financial alchemy: too light lending regulation, years of cheap money, poor supervision, as well as speculation and greed.

${ }^{7}$ T. Barber, 'Barroso must fight threats to single market', Financial Times, 15 September 2009.

${ }^{8} \mathrm{E}$. Vucheva, 'EU governments committed $€ 3$ trillion for bank bailouts', EUObserver, 9 April 2009.

${ }^{9}$ J. Lichfield and R. Russell, 'The Merkel plan: I'll save the euro with a federal Europe', The Independent, 3 December 2011.

${ }^{10} \mathrm{C}$. Moore, 'Jacques Delors interview: Euro would still be strong if it had been built on my plan', The Telegraph, 2 December 2011.
} 
that financial balances deteriorated in the eurozone in the aftermath of the Global Credit Crunch (2007-09). Second, the 3 per cent cap was not respected (and no sanctions applied). Third, Ireland had a balanced budget in 2007, while its deficit soared to over 31 per cent of GDP in 2010. Fourth, the UK (not a eurozone member) strongly increased its deficit from 2006 to 2009 and has since kept it at a relatively high level. Lastly, countries that are outside the eurozone (Sweden) and outside the EU (Norway and Switzerland) apply the Stability and Growth Pact criteria in an exemplary way. The Swiss direct-democracy political system controls government expenditure better than the alternative European and other exterior systems.

Table 2 presents the situation regarding debt in select eurozone and other exterior countries for the period 2006-13. Debt in the eurozone countries increased. This indicates that the world of higher taxes and lower public expenditure may be coming in the future (provided that there is no strong growth). There are several striking features. First, (the deficit criterion) the non-eurozone (Sweden) and nonEU member countries (Norway and Switzerland) apply the Maastricht debt criteria in an exemplary way. Second, the UK almost doubled its national debt in just three

Table 1. Financial balances in select Eurozone and other countries - deficits \% GDP in 2006-13.

\begin{tabular}{lcccccccc}
\hline Country & $\mathbf{2 0 0 6}$ & $\mathbf{2 0 0 7}$ & $\mathbf{2 0 0 8}$ & $\mathbf{2 0 0 9}$ & $\mathbf{2 0 1 0}$ & $\mathbf{2 0 1 1}$ & $\mathbf{2 0 1 2}$ & $\mathbf{2 0 1 3}$ \\
\hline Belgium & 0.1 & -0.3 & -1.3 & -5.9 & -4.2 & -3.5 & -3.2 & -2.2 \\
France & -2.4 & -2.7 & -3.3 & -7.6 & -7.1 & -5.7 & -4.5 & -3.0 \\
Germany & -1.7 & 0.2 & -0.1 & -3.2 & -4.3 & -1.2 & -1.1 & -0.6 \\
Greece & -6.0 & -6.8 & -9.9 & -15.8 & -10.8 & -9.0 & -7.0 & -5.3 \\
Ireland & 2.9 & 0.1 & -7.3 & -14.2 & -31.3 & -10.3 & -8.7 & -7.6 \\
Italy & -3.4 & -1.6 & -2.7 & -5.4 & -4.5 & -3.6 & -1.6 & -0.1 \\
Netherlands & 0.5 & 0.2 & 0.5 & -5.5 & -5.0 & -4.2 & -3.2 & -2.8 \\
Portugal & -4.1 & -3.2 & -3.7 & -10.2 & -9.8 & -5.9 & -4.5 & -3.0 \\
Spain & 2.4 & 1.9 & -4.5 & -11.2 & -9.3 & -6.2 & -4.4 & -3.0 \\
\hline & & & Non Eurozone & & & & \\
\hline UK & -2.7 & -2.8 & -5.0 & -11.0 & -11.4 & -9.4 & -8.7 & -7.3 \\
Sweden & 2.2 & 3.6 & 2.2 & -0.9 & -0.1 & 0.1 & 0.0 & 0.7 \\
Norway & 18.4 & 17.5 & 19.1 & 10.7 & 10.6 & 12.5 & 11.5 & 10.7 \\
Switzerland & 0.8 & 1.7 & 2.3 & 1.0 & 0.6 & 0.8 & 0.5 & 0.6 \\
Japan & -1.6 & -2.4 & -2.2 & -8.7 & -7.8 & -8.9 & -8.9 & -9.5 \\
US & -2.2 & -2.9 & -6.6 & -11.6 & -10.7 & -10.0 & -9.3 & -8.3 \\
\hline
\end{tabular}

Source: OECD Economic Outlook, No. 90, November 2011. 
years following 2007. Ireland more than tripled it in the period 2007-10.

A good lesson, inspiration and direction for the eurozone may be taken from Switzerland and, surprisingly, from Russia. In the decentralised federal state of Switzerland, cantons and communes have high degrees of autonomy and fiscal sovereignty which are strongly protected. Cantonal and local expenditure is, in general, subject to constant scrutiny by the people. Hence, the authorities generally show an admirable degree of financial (self) discipline. The Swiss authorities are trusted, but constantly supervised and verified through referendums. ${ }^{11}$ If an entity borrows too much and is financially irresponsible, it may bankrupt as was the case with the municipality of Leukerbad in 1999. In that case, the municipal assets were sold for the benefit of the creditors. The creditors know in advance that they also bear the risk as there will be no rescue from the cantons or from the federal government. The Swiss authorities consulted the people in a referendum in 2001 and the people decided that the federal budget needs to be balanced. Since then, national debt has declined (Table 2). Budgetary discipline in a monetary union can successfully exist even without supervision from the centre. The problem is whether or not the EU elite would like to dilute its central levers of power and trickle it down to the constituent parts. The Swiss can be admired for their handling of diversity. ${ }^{12}$

Russia ran a huge budget deficit (1993-98), mainly financed from foreign loans. After the 1998 default everyone rightly refused to give loans. Being shut off from financial markets, Russia had to adjust fast and hard. This was done through cuts in public expenditure, predominantly through elimination of public subsidies to firms. This, together with the deregulation of small and medium-sized enterprises and tax reform, contributed to the improvements visible in the competitive positions of production. EU assistance to the countries in trouble was relatively slow and carried out through new loans. Reforms and biting the bullet have been postponed in the EU. Imagine the type of effect new and continued loans for the Russian economy (instead of tough restructuring) would have had in 1998.

In considerations of what may happen if the basic economic-policy ideas concerning deficits between France and Germany are in disaccord, Praussello

\footnotetext{
${ }^{11}$ Feld and Matsusaka (2003) found that direct democracy matters in public expenditure. In cases in which voters participate directly in decisions related to public spending, the Swiss cantons with mandatory referendums had 19 per cent lower spending per capita.

${ }^{12}$ The constituent states in the US have independence regarding taxes. The federal income tax is the only one applied through the union. Taxes are rather low in states such as Nevada (taxing gambling is the principal source of tax proceeds), elsewhere taxes may be high on property or spirits.
} 
Table 2. Financial balances in select Eurozone and other countries - debt \% GDP in 2006-13.

\begin{tabular}{|c|c|c|c|c|c|c|c|c|}
\hline Country & 2006 & 2007 & 2008 & 2009 & 2010 & 2011 & 2012 & 2013 \\
\hline \multicolumn{9}{|c|}{ Eurozone } \\
\hline Belgium & 91.6 & 88.0 & 93.0 & 100.0 & 100.2 & 100.3 & 101.5 & 101.0 \\
\hline France & 72.1 & 73.0 & 79.3 & 90.8 & 95.2 & 98.6 & 102.4 & 104.1 \\
\hline Germany & 69.8 & 65.6 & 69.7 & 77.4 & 87.1 & 86.9 & 87.3 & 86.4 \\
\hline Greece & 116.9 & 115.0 & 118.1 & 133.5 & 149.1 & 165.1 & 181.2 & 183.9 \\
\hline Ireland & 29.2 & 28.7 & 49.6 & 71.1 & 98.5 & 112.6 & 118.8 & 122.4 \\
\hline Italy & 116.9 & 112.1 & 114.7 & 127.1 & 126.1 & 127.7 & 128.1 & 126.6 \\
\hline Netherlands & 54.5 & 51.5 & 64.8 & 67.7 & 70.6 & 72.5 & 75.3 & 76.9 \\
\hline Portugal & 77.6 & 75.4 & 80.7 & 93.3 & 103.6 & 111.9 & 121.9 & 123.7 \\
\hline Spain & 46.2 & 42.3 & 47.7 & 62.9 & 67.1 & 74.1 & 77.2 & 79.0 \\
\hline \multicolumn{9}{|c|}{ Non Eurozone } \\
\hline$U K$ & 46.0 & 47.2 & 57.4 & 72.4 & 82.2 & 90.0 & 97.2 & 102.3 \\
\hline Sweden & 53.9 & 49.3 & 49.6 & 52.0 & 49.1 & 46.2 & 45.3 & 43.1 \\
\hline Norway & 59.4 & 57.4 & 55.0 & 49.1 & 49.7 & 56.5 & 51.3 & 48.6 \\
\hline Switzerland & 50.2 & 46.8 & 43.6 & 43.7 & 42.6 & 42.0 & 41.2 & 40.7 \\
\hline Japan & 172.1 & 167.0 & 174.1 & 194.1 & 200.0 & 211.7 & 219.1 & 226.8 \\
\hline$U S$ & 60.9 & 62.1 & 71.4 & 85.0 & 94.2 & 97.6 & 103.6 & 108.5 \\
\hline
\end{tabular}

Source: OECD Economic Outlook, No. 90, November 2011.

(2011, p. 371) states:

Such a state of affairs could become explosive when a recently passed law introduced into the German constitution comes into effect. The law stipulates that the federal public deficit should be reduced to 0.35 per cent of GDP by 2016 and to zero by the beginning of 2020 . One wonders how it will be possible to coordinate fiscal policies within EMU if Germany and France, not to mention the minor member countries, follow conflicting stances regarding the role of the public deficit as a means to smooth business cycles. Could the resulting tensions be attuned to the stability of the eurozone?

If this happens in the future, the one size-fits-all monetary policy for all eurozone countries at all times and in all circumstance will put the eurozone to a serious existential test.

When the eurozone was created and the cherished German mark was abandoned, the implicit and explicit promise made to the Germans was that the euro:

- would be a glorified version of the German mark

- it would be stable

- financially thrifty countries would not have to bailout the prodigal ones 
- it would bring perpetual growth and prosperity to everyone

- German taxpayers would not foot the bill for all of the above

Were those promises respected and delivered? What the people see is the banking fiasco (2007-09), the eurozone mess (2011), austerity and pain.

The expectation and the implicit promise was that the euro would bring perpetual wellbeing, infinite prosperity and be as solid as a Mercedes Benz over an extensive period of time. Therefore, the project included no life boats for stormy weather in the form of permanent treasury or rescue fund. The project, in reality, turned out to be as fragile as a second-hand Fiat ( $a d$ hoc tinkering and coordination whenever 'surprising' crises appear). Profound changes are necessary to salvage the project. However, such changes would require arrangements to treaties based on the German-constructed template (rigorous fiscal discipline), which is not palatable to many of the blocs countries. Some may even argue that the euro has been contorted into a German 'weapon'.

What can be expected in the future? The most interesting, determining and important developments to observe, analyse and fear are changes in deficits and debts between France and Germany (tables 1 and 2, respectively). These two countries are evolving at different paces. If the yawning gaps between the principal economic indicators (in this case deficits and debts) between Germany and France ${ }^{13}$ (and other countries) continue in the future, what would the outcome be or Germans do at the eurozone's $20^{\text {th }}$ anniversary? Would it be better for them to stay outside of the eurozone?

Table 3 summarises select basic social and cultural differences between France and Germany, the two principal eurozone actors. Those differences are reflected in their views on and handling of EU-related affairs.

Moral hazard is defined as the additional risk taken by actors who suppose and expect that the extra risk taken is, or will be, insured by others. The actors may be individuals, firms or governments. The belief and hope is that their misconduct will not be punished. This is the core misdemeanour and problem of the eurozone. The absence of sanctions ${ }^{14}$ encourages continued misconduct and lures others toward wrongdoing. The casualty of such free-riding is confidence, a factor vital in long-

\footnotetext{
${ }^{13}$ France has also lived beyond its means. Its 1974 budget was the last one on record that was in balance.

${ }^{14}$ Eurozone member states have normally been reluctant to punish each other. There is often a strong cooperation and support among the politicians. They do not slap sanctions on each other. Can one imagine the European Commission punishing Germany, or perish the thought, France?
} 
term social relations. Translated into economics, this is epitomised in higher interest and insurance rates, as well as in higher costs of doing business. This has happened with Greece, Italy and certain other eurozone members. Continued government borrowing was possible, but at unaffordable levels. The interest rates were two or three times, or even more, higher than the ones asked of the frugal borrowers in Germany. High interest rates put in peril the sustainability of debt repayment.

The expectation, plan and hope was that countries with weak currencies and chaotic governance (corruption) would change their behaviour and turn into wellorganised, German-style accountable states once they joined the eurozone. A German (Prussian, Bavarian or Schwabian) housewife has always been a symbol of exemplary housekeeping. As compensation for the loss of national currency, the low interest rates in the euro (as the result of the financial tie to the reliable Germany) would increase the competitiveness of their output. By accepting the solid euro in place of their dubious national currencies (which could be devalued), those Southern European countries entered a cage. Instead of 'turning German' in the eurozone, the available cheap and easy credit made those countries go on a spending spree as if nothing had happened. These countries did not became cautious and thrifty. The efficient German producers boosted their exports, which

Table 3. Select basic differences between France and Germany.

\begin{tabular}{|c|c|c|}
\hline Issue & France & Germany \\
\hline $\begin{array}{l}\text { Political organisation and } \\
\text { overall governing spirit }\end{array}$ & $\begin{array}{l}\text { Elite-type leadership and } \\
\text { practical decision making } \\
\text { (fast moving) }\end{array}$ & $\begin{array}{l}\text { Rule of law and democratic } \\
\text { nstitutions (a rather slow } \\
\text { process) }\end{array}$ \\
\hline $\begin{array}{l}\text { Role of the state in the } \\
\text { economy }\end{array}$ & Principal actor & $\begin{array}{l}\text { State is a rules-making institution } \\
\text { and a referee, while principal } \\
\text { actors are in the private sector }\end{array}$ \\
\hline Deficit & A rather more lax approach & A somehow more strict approach \\
\hline Inflation & $\begin{array}{l}\text { Long standing and rather } \\
\text { 'friendly' relation }\end{array}$ & $\begin{array}{l}\text { Fundamental aversion } \\
\text { embedded in any government's } \\
\text { 'genetic code' }\end{array}$ \\
\hline Fiscal union & Increased budgetary solidarity & Greater financial discipline \\
\hline Economic priorities & Economic growth (inflation) & $\begin{array}{l}\text { Financial orthodoxy } \\
\text { (inflation aversion) }\end{array}$ \\
\hline Demography till 2050 & $\begin{array}{l}\text { Stagnant or slightly increasing } \\
\text { population, in particular } \\
\text { immigrant population }\end{array}$ & Shrinking population \\
\hline Britain in the EU & Trouble & Problem \\
\hline
\end{tabular}


had a strong stimulative effect on their domestic economy. This created huge imbalances in trade (Germany had a surplus). As time passed, it became prohibitively expensive for the weak states to borrow funds to service the accumulated debt. Illusion and false expectation of the uniformity in human and social behaviour is to be blamed in part for the fiasco.

Another issue that analysts and policymakers need to keep in mind in the eurozone is demography. Populations are rapidly ageing throughout Europe. The baby-boom generation started to retire on a larger scale from 2010 onwards. They have the right to have their old age pensions guaranteed by the state. The predominant pay-as-you-go pension system operated well when demographical satiation was favourable. Now the situation is different. The number of taxed contributors to the social fund is fixed or shrinking, while the number of beneficiaries (retired) is expanding because of the retired baby-boomers and because people now live longer. This will create an additional strain on already overstretched government deficits. There is no sliver bullet that can solve this situation in a smooth way. The solutions are rather bitter: people have to work and contribute to the budget/funds longer in their lifetime; the retired need to accept a reduction in pensions; taxpayers need to pay higher taxes, while governments ought to balance these bitter medicines and provide incentives for higher productivity. The technocratic (unelected) governments in both Greece and Italy are doing just that.

Table 4 presents the pensions gap in select countries in Europe. The burden on government finances is enormous, and it may well get worse if the state-guaranteed pension system is not reformed (slimmed down). The table also shows that if the French and the Germans want to keep their current consumption at the same level during retirement, per person they ought to save $€ 7,960$ and $€ 11,600$ a year, respectively. Workers across the EU need to save $€ 1,900$ billion more each year if they hope to retire with pensions that will maintain their standard of living. ${ }^{15}$

\section{Deficits: Conflicting Policy Advices}

Economics offers conflicting and confusing advices to policymakers regarding the basic problem related to public deficits. There are two basic schools of thought: the Ricardians and the Keynesians. The Ricardians would argue that budget

\footnotetext{
${ }^{15}$ P. Davies, 'Survey finds $€ 1,900$ bn hole in EU pensions', Financial Times, 21 September 2010.
} 
Table 4. Savings and retirement income gap.

\begin{tabular}{lccc}
\hline Country & $\begin{array}{c}\text { Annual pensions } \\
\text { gap, Country } \\
\text { total }(€ b n)\end{array}$ & $\begin{array}{c}\text { Annual pensions } \\
\text { gap as a \% of } \\
2010 \text { PPP GDP }\end{array}$ & $\begin{array}{c}\text { Annual pensions gap } \\
\text { (all individuals retiring 2011-51), } \\
\text { Average Per Person (€000) }\end{array}$ \\
\hline France & 243.5 & 17 & 7.96 \\
Czech & 25.3 & 14 & 4.6 \\
Republic & 468.8 & 24 & 11.6 \\
Germany & 9.5 & 7 & 1.9 \\
Hungary & 20.2 & 17 & 9.1 \\
Ireland & 97.6 & 8 & 3.1 \\
Italy & 5 & 13 & 3 \\
Lithuania & 68.8 & 14 & 3.4 \\
Poland & 40.2 & 23 & 3.7 \\
Romania & 170.5 & 18 & 7 \\
Spain & 379 & 26 & 12.3 \\
UK & 401.7 & 27 & 5.8 \\
Russia & 91 & 14 & 2.4 \\
Turkey & 'S & & \\
\hline
\end{tabular}

Source: P. Davies, 'Survey finds $€ 1,900$ bn hole in EU pensions', Financial Times, 21 September 2010.

deficits and increased public expenditure aimed at stimulating the economy would lead to a new recession and inflation. Debt problems cannot be solved with more debt. Debt relief is a reward to the undeserving. If there is massive extra liquidity, this would bring hyperinflation. They also argue that 1 per cent of extra public spending produces less than 1 per cent increase in GDP. The problem with this school is that when debtors (and the government) spend less, the economy will continue to remain depressed, unless somebody else in the economy spends more. Home sales at a huge loss in Ireland, Spain or in the US (California, Florida, Nevada) is a punishment for excessive borrowing and taxpayers should not bear the burden of such hazardous and wrong investment bets made by others. However, if there is no extra expenditure, the Ricardians may be perpetuating the existing crises and, eventually, endanger their own jobs.

The Keynesians, on the other hand, would argue just the opposite. Deficits are necessary to avoid deflation. Without deficits, recession would be deeper and longer. Expanded new liquidity reflects the fact that the banks hoard funds, and when the economy improves and when banks start lending, the central bank may withdraw extra liquidity as fast as it injected it, hence there is zero risk of inflation (has this ever happened?). According to this school of thought, 1 per cent of extra public spending produces more than a 1 per cent increase in GDP. Rather than 
punishing the unworthy, debt relief and fiscal stimulus are necessary, otherwise high unemployment will self-perpetuate.

Who is right? The Ricardians or the Keynesians? What advice should be given to policymakers? Many hesitate in this confusing situation. It seems that the US and France are (after the Global Credit Crunch) more on the Keynesian side, while Germany, Ireland and Britain ${ }^{16}$ are in the Ricardian camp. It was thought before the Global Credit Crunch that rational expectation exits, and that free market forces are best able to facilitate the smooth operation of the economy. That was the principal ideological 'game in town' that led to the large-scale financial deregulation seen in the US over the past few decades. The initial financial loss from the Global Credit Crunch is put by the International Monetary Fund (IMF) at $\$ 4,100$ billion. ${ }^{17}$ In this situation one wonders: what kind of bigger loss is necessary to convince policymakers that this type of overly light market regulation has failed. ${ }^{18}$ And failed on a grand scale. Rational expectations and calculations on the behaviour of rational agents do not conform to an all too complex real world.

There were warnings being voiced about a train crash in the making well before the EMU took effect. Jovanović $(1997$, p. 68) argued in favour of the postponement of the implementation of the EMU as the conditions were not yet becoming for such a crucial integration step. Having doubts about the eurozone, 155 university professors of economics from Germany signed a declaration in 1998 for an orderly postponement of the implementation of the EMU. ${ }^{19}$ The reasons pertained to the unsuitable economic conditions in Europe. It is hard for two economists to agree on anything; having a choir of 155 of them speaking with one voice is an extraordinary event. However, this and other appeals were neglected. Who said that reason and wisdom rule the world? The EU elite that pushed the project ahead saw only the inevitable and shining triumph of the euro over other visions of the future. Basically, the euro and all involved would be transformed to

\footnotetext{
${ }^{16}$ The British government has a bold plan to cut public employment by 490.000 workers. This is at the time when the private sector is in no position to provide alternative employment. The reason has to do a lot with ideology: the Tories want to downsize the welfare state. 'The best guess is that Britain in 2011 will look like Britain in 1931, or the United stares in 1937, or Japan in 1997. That is, premature fiscal austerity will lead to a renewed economic slump. As always, those who refuse to learn from the past are doomed to repeat it' (P. Krugman, 'British fashion victims', New York Times, 22 October 2010).

${ }^{17}$ S. O'Connor, 'IMF puts financial losses at \$4,100bn', Financial Times, 21 April 2009.

${ }^{18}$ Market economy is alive and kicking. Only this type of too lax approach to the market failed. There are many other approaches to 'organise' or assist markets.

${ }^{19} \mathrm{~W}$. Kosters et al, 'German economics professors convinced 'orderly postponement' of euro essential', Financial Times, 9 February 1998.
} 
be as virtuous as the German mark. Users were expected to like the euro because of its stability, economic prosperity and global influence. Politics won over economics. A decade later, the euro is linked with austerity, instability, debt and pain, as well as an uncertain future.

\section{Expanding or Breaking up the Eurozone}

The eurozone expanded its membership, which shows its attractiveness, even success. However, the credibility of the eurozone is based on a promise - a credible promise for the time being - to pay. But it is still an international promise which ought to be tested over time and, especially, during lean times and crises. European history is full of such promises that were not honoured. For example, the Latin Monetary Union (1865-1927) included Belgium, France, Italy and Switzerland (Greece joined in 1868), while Denmark, Sweden and later Norway belonged to the Scandinavian Monetary Union (1873-1914). Apart from insufficient economic convergence among the economies of the involved countries, high and diverging rates of inflation, the domino effect in banking crises and a lack of political union that could enforce policies were always among the principal causes for their demise. The same holds for the Austro-Hungarian, Czechoslovakian, ${ }^{20}$ Soviet and Yugoslav economic unions towards the end of their existence.

The real problem for governments is related to the issue of how to honour international promises and, at the same time, please domestic voters, if they matter. As long as governments are sovereign (no political union), the eurozone will have the potential to break up (the risk of a break-up is not zero). Monetary unions in Europe have a limited shelf life; break ups have always been a risky idea. ${ }^{21}$ In any case departure, from monetary unions has been common and a familiar eventuality in Europe over the past two centuries. There was always an initial 'shock' for a country after departure, but ultimately the effects were temporary.

If a eurozone country is shut out of an open capital market or the loan terms are prohibitive (as was the case with Greece), the country is destined to have a permanent slump. It is forced to make painful reforms and it may encounter the temptation to re-introduce its national currency. This currency may be devalued and printed 'freely'. The problem is that while the introduction of the common

\footnotetext{
${ }^{20}$ The breakup of the Czechoslovak monetary union is a rare one that took place in stable circumstances.

${ }^{21}$ Many countries that emerged from the former Soviet Union found it hard to go it alone and were looking for a certain re-linking with Russia.
} 
currency, the euro, was orderly (it was introduced on the basis of a detailed plan, timetable and fixed exchange rate), the reverse operation would not be orderly. It would be noisy, nasty and involve anger and panic. The cost would be enormous and hard to estimate. These costs would include a run on the banks to avoid forced conversion into a new and weak currency, as well as the logistical nightmare regarding conversion of contracts, bonds, deposits, mortgages and wages. Even though the exiting country could have its own (devalued) ${ }^{22}$ currency, it would still face payments of foreign loans in euros. Benefits that may come from the breaking of a monetary union (or leaving it) may be volatile. ${ }^{23} \mathrm{~A}$ country may devalue and increase exports, in particular if it has low import dependence (inputs) of its exports.

The root cause of weak competitiveness of national goods and services on international markets has most often been low productivity, lack of innovation, rigid wages and a meagre flow of labour from low to higher productivity industries. Devaluation may help a country only temporarily, but it does not eliminate the root causes of low competitiveness. Hence, the potential benefit of the breaking up of a currency union (in the EU) or an exit from it may be rather slim in the longer term unless the competitiveness and productivity issues are addressed.

If Germany finds that it is not worth staying any longer in the eurozone and opts to leave it has to keep in mind that its export-dependent economy would suffer heavily. The value of the new German mark may soar, while other EU countries would devalue. The Single European Market would unravel (customs posts may need to be reintroduced). German exports would suffer with consequences for German (un)employment. As Germany benefits enormously from the eurozone (exports of goods and capital), it would not easily let it collapse. However, suppose a situation in which Germany is asked to transfer billions of euros to the peripheral eurozone countries at a time when it cuts welfare benefits to domestic citizens (and voters). Germany would no longer tolerate that its capital exports and various types of subsidies are spent in the poorer eurozone areas on private property, early retirement schemes and on assistance to other countries, rather than on productive investment.

\footnotetext{
${ }^{22}$ Devaluation will be inevitable as nobody will want this new currency especially at a high rate of exchange.

${ }^{23}$ Slovenia is an example of the country that broke up from the dysfunctional Yugoslavia and successfully went on its own in 1991. None the less, it joined the EU in 2004 and the Eurozone in 2007. A larger group is still attractive in certain cases. However, would it be also the case now for Norway and Switzerland having in mind data presented in Table 1 and 2, respectively?
} 
The problem was not that the flow of capital toward the eurozone periphery took place. The problem was that it ended up in the property bubble (real estate gamble) first, and in the commodity price gamble afterwards. Who is to blame? The culprits are obvious: defective banks, the snowballing herd-like behaviour of investors, as well as imprudent governments. Not the euro. Countries such as the US, Britain, Iceland and other non-eurozone countries (Hungary) had property bubbles too. Being in the low-interest rate eurozone only provided the possibility to the Irish and Spanish of getting cheap loans to invigorate the property boom. Low cost financing gave entrepreneurs the opportunities to undertake too many projects at the same time. Capital was misallocated and wasted in certain projects (too many houses and apartments remain empty and cheap). In the case of Spain, the migration of (affluent) foreigners into those cheap properties may be better than the emigration of Spaniards elsewhere.

\section{The Eurozone Country Crises}

\section{A. Greece}

The eurozone's 'social contract' was that the euro would be as solid as the German mark and that governments would be as careful and thrifty as Germany wants (them) to be in order to maintain confidence in and the stability of the euro. So much for that theory. Everybody knew that Greece joined the eurozone in 2001 with the assistance of some 'creative accounting' and by supplying 'adjusted' statistics on deficit and debt. Still, the top eurozone elite kept a blind eye to this. They wanted to have Greece in the project, and they got it. Nonetheless, it needs to be noted that the Greek government and the Bank of Greece made enormous efforts over the course of four years to normalise the monetary and fiscal conditions to qualify for the eurozone.

Greece is a country that emerged from civil war and dictatorship. As a result of this situation, national consensus-building had a rather feeble roots. The successive Greek governments were buying social peace and votes by the means of public spending and state borrowing. Greece had swollen social corruption and a tax system as leaky as a sieve. This type of large scale social bribery was between the politicians and the people. In return for votes, politicians promised political patronage (rousfeti in Greek) and state-related jobs, not highly paid but safe, $13^{\text {th }}$ or even $14^{\text {th }}$ month salaries and various social benefits. The pension system allowed 
people to retire in their 50s with a pension equal to 90 per cent of their final salary. The public sector swelled. Being in the eurozone gave Greece the credibility to continue borrowing at lower rates of interest than would have been the case had it been on its own. As such, the governments were subject to an array of rent seekers and various interest groups. Consequently, deficits and debt in Greece did not appear suddenly, as in an earthquake, but were accumulating over decades. Such poor policies were tolerated over a long period of time. The Greek god of wine, sumptuous parties and enjoyment, Dionysus, had his festival season during the time of populist policies.

Once debt reached the level at which the financial markets offered loans to overindebted Greece at interest rates of 10 per cent (three times higher than they were charging Germany at the same time [spring of 2010]), the eurozone crises erupted. Neither the Greek not other EU economies are wired to operate at such high interest rates (and sovereign risk), as this translates into a decline in investment activity and employment. The problem is that the rates on loans to the countries in trouble were for years higher that the expected recipient countries' growth rates. Greece or Italy, for instance, could not service their debt. Such high interest rates would prove disastrous for the fragile private sector. Many other eurozone countries were in a recession or limping out of it.

Bankers in Europe were lending to the 'prodigal' Greece in the full knowledge that the loans would not be repaid. In fact, sales to Greece were strongly encouraged. Ferrostaal, the German arms producer, was fined ( $€ 149$ million) in 2011 for giving $€ 62$ million in bribes to the Greeks to buy submarines. ${ }^{24}$ Once cheap loans ceased, Greece entered a phase in which its economy is on the brink of a collapse: output is falling, unemployment is increasing and capital is leaving while bankruptcies spread. ${ }^{25}$ Which country is able to devote some 15 per cent of its $\mathrm{GDP}^{26}$ a year for loan repayment, more than its expenditure on health? Would democracy thrive in such an environment? The bankers also share the blame and responsibility for engaging in such foolish lending policy. If the Greeks cooked their accounts and statistics, it was with full knowledge and collaboration with the pan-European elite. The bankers were also fully involved in this reckless lending and made (initially) profits on loans that they knew were bad all along. The

\footnotetext{
${ }^{24}$ 'Ferrostaal shareholders approve EUR149 million fine in bribery case', The Wall Street Journal, 14 October 2011; Pitelis (2012, p. 8).

${ }^{25}$ Small businesses, once the backbone of the Greek economy and employment, are the heaviest losers.

${ }^{26}$ Greece may need to do that in the coming years.
} 
political currency that they counted on with such toxic financial assets was the expectation that the European taxpayers would ultimately foot the Greek bill.

The temporary assistance programme 'saved' Greece. Some saw that as a sign of eurozone solidarity. It was to an extent. However, the money lent to Greece did not go through the Greek economy, but was destined mainly for the payment of Greek interest rates for loans. The bailout was to save foreign banks from taking the hit, i.e. avoiding punishment for their absurd loans and preposterous lending policies. To put it bluntly, Germany was not 'saving' Greece, but rather the domestic bankers and taxpayers. German banks' direct exposure to various forms of debt in Greece, Portugal, Spain and Italy stands at around $€ 520$ billion. ${ }^{27}$ Regarding Greece, the German 'credit card' was (temporarily) saved on the back of the Greeks, many of whom lost or will lose their jobs. Responsibility is shared, while the penalty weighs on one side only (so far). The Greek economy and its businesses are starved of funds at affordable terms. The restoration of growth, so necessary in crises, will suffer heavily for years to come.

Figure 1 shows the great initial success of the eurozone during the years 200007. Eurozone membership reduced risk related to government bonds between different countries, so there was almost no difference between the strong EU core and a rather weak EU periphery. They all converged to the low-risk German level. The assumption made by investors was that the Greek, Italian or other government bonds were almost perfect substitutes for the low-risk German ones. The crises revealed that this was not the case. During the 'happy hours' (2000-07) the Greeks, Italians and others borrowed a lot at low rates that their economies did not merit. Such irresponsible borrowing had a full counterpart in reckless lending across Europe. After 2007 the financial market reacted to the alteration in the perception of risk (the origin of crises was not a speculative attack on the euro). National bond yields are turning back towards their historical averages. The Roman god Bacchus may as well join the Greek god Dionysus and close shop for a while. The party is over.

What could a country in trouble (such as Greece) and the eurozone do in such a situation? There are four theoretical options:

(1) Greece could raise taxes and reduce expenditure in the future. This would aggravate the unemployment problem. In addition, privatisation of public enterprises means inevitably that certain employees would lose their jobs.

\footnotetext{
${ }^{27}$ Stratfor, 'Germany: creating economic governance', 14 May 2010.
} 
(2) Greece could seek bailout from eurozone partners. Germany and France feared that such a bailout would create a precedent for other countries. If the EU refuses 'assistance' to Greece, the crises could spread to Ireland, Portugal, Spain, Italy or Belgium (these are countries that face an increase in the cost of borrowing). In the case of the eurozone bailout, EU officials would, in practice, seize control of the Greek Ministry of Finance. Greece, in this case, would in effect become the 'eurozone colony'. Before going that far, the EU may try to persuade Greece to 'do the necessary':

- cut wages to make production internationally competitive which would create new jobs at home ${ }^{28}$

- increase productivity

- cut expenditure for health, education, pensions and various social services

- reduce public employment

- widen the tax base

Greece ought to do the above all on its own as in the EMU devaluation of its

Figure 1. European bond yields (10-year bonds, percent).

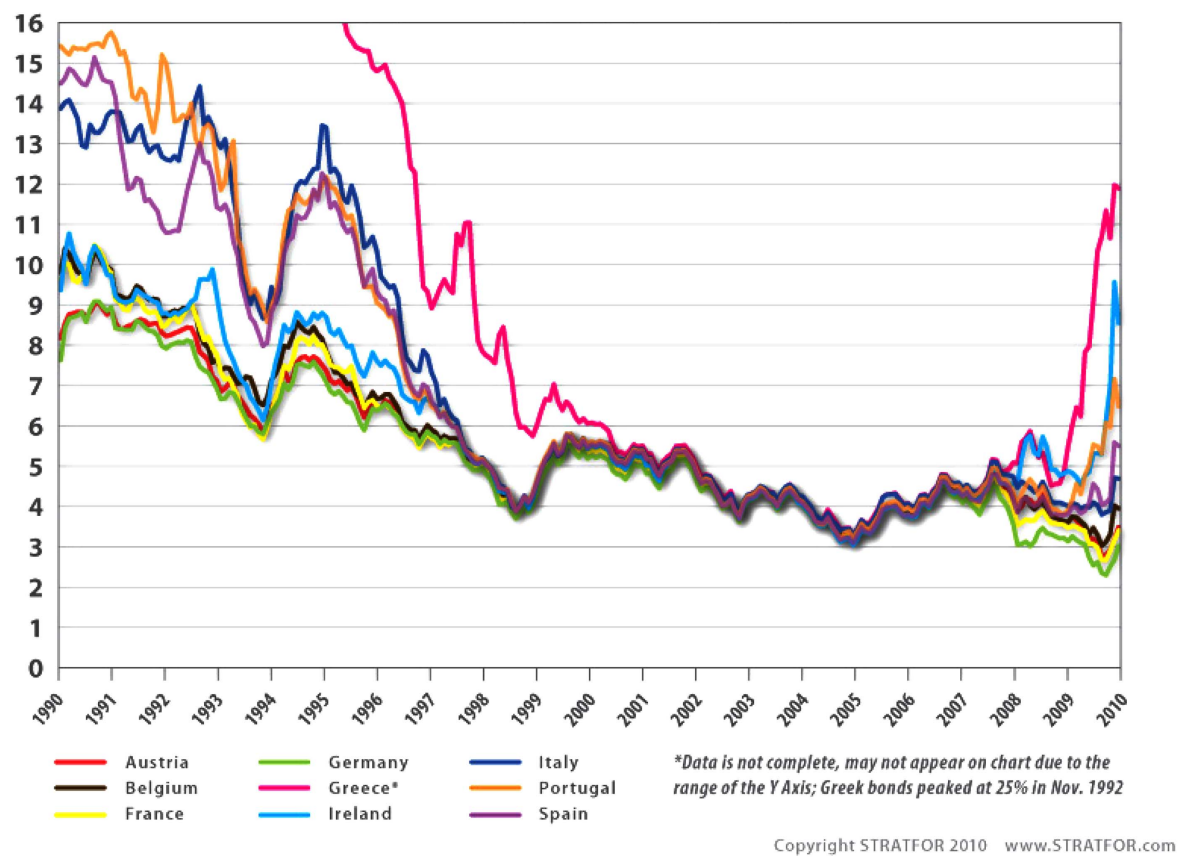

\footnotetext{
${ }^{28}$ This does not mean that Greece needs to produce and export more olives to Germany. More than that is necessary.
} 
currency is impossible. Inflating out of crises is not possible. The eurozone (Germany) may need to provide aid (transfers) to make the above hard economic medicines bearable. Experience has shown that successful paper currencies in monetary unions are backed by a considerable common budget.

(3) The Greeks may also make promises that their policy would improve in the future and ask for easier treatment now. This would push the problem towards future generations. This option could put the weakly-governed eurozone (lax monitoring and easy compromises) to breaking point in the future.

(4) If nothing of the above works, Greece can:

- Leave the eurozone temporarily. Greece would be obliged to return to the eurozone as soon as its situation improves. This may be more acceptable for the EU than to have Germany leave the eurozone.

- Leave the eurozone permanently.

It was the credibility of both the eurozone and Greece that was at stake in the spring of 2010. Therefore, the eurozone ought to have (permanent) crisis resolution tools and procedures. Can this be achieved without stronger federalist moves towards a political and fiscal union? Should the governments forget what they promised citizens when they created the eurozone?

Article 125(1) of the Treaty on the Functioning of the European Union contains a clear no bailout clause. It states:

The Union shall not be liable for or assume the commitments of central governments, regional, local or other public authorities, other bodies governed by public law, or public undertakings of any Member State, without prejudice to mutual financial guarantees for the joint execution of a specific project. A Member State shall not be liable for or assume the commitments of central governments, regional, local or other public authorities, other bodies governed by public law, or public undertakings of another Member State, without prejudice to mutual financial guarantees for the joint execution of a specific project (emphasis added).

This is a legal request that each country has a responsibility for monitoring the prudence of its own finances. Other member countries and the EU are not responsible for the prodigal country's financial troubles. This article also states that the EU or its member countries may not be forced to bailout a member country. 
However, there is also Article 122(2), which reads:

Where a Member State is in difficulties or is seriously threatened with severe difficulties caused by natural disasters or exceptional occurrences beyond its control, the Council, on a proposal from the Commission, may grant, under certain conditions, Union financial assistance to the Member State concerned.

This provides legal grounds for EU assistance to a country in trouble (a possibility of a sovereign debt default). ${ }^{29}$ Hence, the only necessary factor is the political will and readiness to help such a country.

How to assist Greece? This is the country that cannot devaluate its currency, a country which is operating in a tough global economic environment, a state which used to have a very strong domestic banking system (negatively affected by the current domestic fiscal crises) and that has a feeble national consensus on the deep reform process and its final objectives. If liquidity is offered at too high (penalising) a rate, this could aggravate the problem. If the EU writes a blank cheque to Greece, this would be unacceptable to Germany. If the EU takes over Greek public finances, this would hardly be acceptable for the politics of a sovereign state.

Fearing the chain of national defaults, the EU agreed in May 2010 on the first temporary (three-year) rescue package. Greece got $€ 110$ billion in loans ( $€ 70$ from the eurozone and $€ 40$ from the IMF). The condition was that Greece must reduce

\footnotetext{
${ }^{29}$ Sovereign debt is a firm and credible promise by a government of a country to pay back those who lend it funds. This debt is the value of bonds issued by that country's government. While government debt is issued in the domestic currency, sovereign debt is issued in a foreign or common currency. Default on sovereign debt happens when a country's debt obligations are bigger than its capacity to pay it back in full and on time. Defaulting on sovereign debt can be more complex and difficult than defaults on corporate debt because domestic assets cannot be seized to pay back funds. Rather, the terms of the debt need to be renegotiated with the creditors. The investors need to be convinced that the country's hardship concerns current and temporary liquidity (the situation which will permit the assisted country to eventually repay its debt in the future), rather than solvency (when the country will not be able to do that). The lender/investor is left in an unfavourable situation and suffers losses ('haircut'). The sovereign debt default may turn the government into turmoil and the country in question in havoc which is devastating for domestic and foreign investment and the economy.

A few additional definitions:

Default: The holder of a government bond is not paid in time or in full as stipulated in the contract. Bonds loose a (big) part in their value ('haircut').

Restructuring: A charismatic term for a default.

Haircut: A reduction in the value of a bond (investor's loss).

Rescheduling: An agreement to accept payment on a later date
} 
its budget deficit from 13.7 per cent in 2009 to below 3 per cent in 2013; cut public sector salaries and pensions and freeze them for three years; there would be no seasonal bonuses; there would be an increase in taxes on fuel, alcohol and tobacco; and the VAT rate ought to increase. This is perhaps one of the greatest and most challenging economic adjustment efforts in history. It provoked a bombing backlash in Greece in November 2010, not only because of sharp expenditure cuts, but also because of the additional loss of national sovereignty to the EU and the IMF. The omens about the success of the programme are not most encouraging. Very hard times are awaiting Greece, in or out of the eurozone.

Any involvement of the IMF is a big shame and a huge loss of prestige for national or group authorities. It shows a failure in the competence to manage national or group economic policy in a prudent way. When there is nobody left anywhere to offer a loan, the IMF is the very last resort. It does so with conditions firmly based on economic thinking from the 1960s. IMF programmes rarely succeed and always leave harsh results for the national economy and society involved. Countries such as Argentina and Brazil were paying back IMF loans in advance during the first decade of 2000, just to get rid of the IMF's severe policies, which brought hardship and misery.

In addition to the $€ 110$ billion first loan package for Greece, there was an intergovernmental agreement which created the Emergency Funding Facility that disposes of $€ 750$ billion ( $€ 440$ billion form eurozone members; $€ 60$ billion from the EU budget; ${ }^{30}$ and $€ 250$ billion from the IMF). This arrangement is agreed for a period of three years. As it is temporary, the question that arises is what happens once it expires?

The (temporary) bailout of Greece was hailed by eurozone enthusiasts as a sign of solidarity with a member country, and a federalist step towards a kernel of a fiscal union. Conversely, eurozone sceptics saw the move as a punishment of a profligate member country.

As the first rescue package given to Greece in 2010 was insufficient to avoid default, the eurozone Council of Heads of States and Governments decided in July 2011 to assist Greece again in the exceptional and unique financial situation. This was to be disbursed in 2012. The second bailout was a $€ 130$ billion loan at a low interest rate, with a ten year-long grace period and repayment due in 30 years. The intention was to ensure overall eurozone financial stability. The loan terms

\footnotetext{
${ }^{30}$ This portion of the Facility is easiest to activate.
} 
(austerity) were harsh, and provoked public protests. ${ }^{31}$

New debt is used to repay old debt! Is this helping the 'cancer' or the patient? Suspicious of long-term Greek ability to repay the combined loans ( $€ 240$ billion), Finland initially demanded loan collateral. However, the important 'rescue' loanrelated issue is somewhat concealed. Most of the funds from the loan package will not touch the Greek economy at all as the loaned money will be used to pay off the banks that hold the Greek debt. Bankers assist bankers, while the Greek economy may become ungovernable and enter free fall. This may be the surest way out from the eurozone and towards economic chaos.

The bailout deal only provided temporary breathing time to the politicians and bankers. This time may be best used for realising that it may be better to write off (the biggest part) of the Greek debt rather than to underwrite it, the reason being that Greece has been in continuous recession for five years. Economic prospects are dismal. This is the biggest problem for Greece. Without growth, mere austerity will not be able to create the necessary conditions in which Greece can pay its debt. The necessary boost to the economy could come from a Marshall-esque form of assistance (including public works), otherwise mere austerity would only prolong and deepen crisis.

\section{B. Ireland}

During the economic boom years, the 'Celtic tiger' paid insufficient attention to its ambitious banking industry and the exuberance which fuelled the property 'bubble'. The banks borrowed cheaply from abroad to invest in the domestic (and in the British) real estate market. This excessive lending stimulated an expansion in property construction which turned Ireland strongly dependent on the income that flowed from it. The value of the housing stock in Ireland quadrupled during the

\footnotetext{
${ }^{31}$ 'How are the European leaders helping Greece?

The 17 members of the euro currency bloc were expected to put a lending facility of $€ 130 \mathrm{bn}$ ( $£ 108 \mathrm{bn}$ ) on the table, in addition to the $€ 110 \mathrm{bn}$ lent over the last two years.

These loans will replace ones previously offered by foreign banks, which have refused to lend Greece more money. Non-euro nations in the broader 27-strong European Union, including the UK and Sweden, have turned their back on Greece.

What about a helping hand from the private sector?

Banks that lent Greece funds over many years have accumulated $€ 205 \mathrm{bn}$ of outstanding loans, packaged as bonds of varying maturities. In total, the Greek state has $€ 350 \mathrm{bn}$ of debts. A major grouping of banks, led by Deutsche Bank, have agreed to swap their holdings for new 30-year bonds and accept a $70 \%$ loss in the process. This will bring down Greece's debt-to-GDP ratio from $160 \%$ to a still scarily high 130\%' (P. Inman, 'Q\&A Greek bailout: anatomy of a deal', The Guardian, 20 February 2012).
} 
years $2000-06 .^{32}$ The real estate market started to cool off in 2006 and reached its peak in 2008. Houses and apartments were empty and did not generate rent income. The banks were also cut off from cheap wholesale funds, so the property bubble blew up. ${ }^{33}$ Investors and banks (Irish and British) suffered disastrous losses on their property-related investment bets. On the eve of the crisis in 2006, Irish public debt stood at 29 per cent of GDP, which was the lowest in the eurozone (the German figure was 70 per cent) (Table 2). The Irish Government rushed to guarantee (a mistake?) not just the depositors in Irish banks, but also their bondholders (recapitalisation) ${ }^{34}$ leading to the deficit soaring from 0 per cent of GDP in 2007, to over 7.3 per cent in 2008, over 14.2 per cent in 2009, and to more than 31 per cent of GDP in 2010 (Table 1) over 10 times the eurozone budget deficit ceiling. Public debt tripled in the period 2006-10. ${ }^{35}$

Why was the Irish government intervention a mistake? Wolf explains this succinctly: ${ }^{36}$

The first duty of the state is to save itself, not to load its taxpayers with obligations to rescue careless lenders. If the eurozone is not a "transfer union", that has to work both ways: taxpayers of one state should not rescue those of others from having to save their banks from their follies.

The Irish state should have saved itself by drastic restructuring of bank liabilities. Bank debt simply cannot be public debt. If bank debt is to be such debt, bankers should be viewed as civil servants and banks as government departments. Surely, creditors must take the hit, instead.

Outside the eurozone, Ireland's currency would be much weaker than the euro. This devalued currency would stimulate exports, but Ireland would have to pay more for its imports, which would translate fast into inflation. The net exportrelated benefit would therefore evaporate fast. In the absence of direct devaluation, Ireland needs to do the same indirectly by reducing prices and wages to restore the competitiveness of its output. A reduction in wages is important as the 'Celtic tiger' permitted their increase during the relatively prosperous years (2000-05) at a

\footnotetext{
${ }^{32}$ P. Legrain, 'Don't blame the euro for Ireland's mess', Financial Times, 17 November 2010.

${ }^{33}$ Rents are coming down in Ireland which is conducive to foreign direct investment in certain industries.

${ }^{34}$ P. Legrain, 'Don't blame the euro for Ireland's mess', Financial Times, 17 November 2010.

${ }^{35}$ Differences between Greece and Ireland are important. The European Financial Stability Fund did not exist at the time of the Greek crisis (spring 2010) which contributed to the financial 'panic'.

${ }^{36} \mathrm{M}$. Wolf, 'Why the Irish crisis is such a huge test for the eurozone', Financial Times, 30 November 2010.
} 
rate twice that of the rest of the eurozone.

Even though Ireland did not have an immediate (short-term) need for the eurozone bailout assistance, large eurozone countries insisted that it had to take one from the European Financial Stability Fund (see below). Ireland is a special country in the EU as it trades more with the US and Britain (separately) than with Germany. This economic 'separation' from the German-dominated EU allowed Ireland to do things differently from other EU countries. Ireland voted down both the Nice and the Lisbon EU treaties (and was 'persuaded' by the rest of the EU to have an encore each time with the externally 'suggested' outcome). The Irish are doubtful about the intentions of Germany, France and the European Commission as they fear that one of the background intentions is the wish to 'discipline' Ireland for its low and highly competitive 12.5 per cent tax rate on corporate profit. This low corporate tax rate is so cherished by all segments of Irish society that they all agree to accept increases in the VAT rate and in personal income taxes, rather than touch the profit of corporations.

The question for Ireland was to choose between its own solvency and the solvency of its banks. This Hamlet-type question may soon arise for other European countries, no matter if they are in or out of the eurozone. Borrowing from the European Financial Stability Fund and the IMF is mortgaging the future incomes of citizens and taxpayers to pay the loan back. ${ }^{37}$ In November 2010 Ireland gave in. The EU-IMF rescue package of $€ 85$ billion for a period of sevenand-a-half years had tough conditions: expenditure cuts (welfare and education) and tax hikes (income and property). Hardest hit would be people with fixed incomes. In addition, Irish taxpayers need not endure absolute hardship to pay of foreign investors such as the US hedge funds and various European banks that recklessly gambled and lent to the Irish. These foreign investors may also need to have a 'haircut' on the value of their hazardous and speculative investment, otherwise Irish taxpayers (and the Irish pension funds) would find themselves in debt bondage to transfuse wealth to these gamblers. If this haircut arrives and if such investors expect harsh treatment in future crises, they would be reluctant to invest.

\footnotetext{
${ }^{37}$ The choices are bad for taxpayers. 'I recently discovered a fraudulent transaction on my credit card. Someone has imposed a $£ 5,000$ debt on me without my agreeing to it. That is against the law and I expect I will not ultimately be forced to repay the debt. During the financial crisis, the British government borrowed tens of billions of pounds, of which they require me to repay my "fair share" through taxation. This broke no law and to avoid paying I will have to emigrate' (J. Whyte, 'Why our masters insist on breaking the rules', Financial Times, 8 June 2011).
} 
The bailout provoked additional sovereignty-related concerns in Ireland. Irish pride was at stake. No Irish voter wants economic policy to be dictated from Brussels, Berlin or London. Some even questioned whether the sacrifice made by Patrick Pearse and other Irish independence fighters during the 1916 armed Easter uprising against British rule had been in vain. The looming recession or slow growth would turn Ireland from an immigration magnet country (1995-2005) towards a country from which the young and educated emigrate once more.

The potential collapse of the Irish banks would hurt the German and the French banks too. The Irish owe German investors $€ 138$ billion and French investors $€ 50$ billion. ${ }^{38}$ A possible Irish default could trickle down to other bigger eurozone countries such as Spain and Italy. If this eventuality arrives, then anything may be possible. ${ }^{39}$ At that moment, no country would have the financial means to bailout all eurozone-rim countries. Hence, just like in the case of Greece, the Irish were bailing out foreign private investors (gamblers) to prevent the crisis spreading to other eurozone countries.

\section{Spain}

Greece, Ireland and Portugal are the eurozone 'minnows'. Spain and Italy are the 'whales'. Spain had a huge property bubble linked with a huge rise in privatesector debt (property speculation like in Ireland). Regional banks (cajas) were at the heart of a decade-long property boom. The consequential budget deficit came primarily as a result of reduced tax revenues that depended heavily on real-estate transactions. The deficit was not the consequence of reckless public expenditure, as was the case in Greece. Recession-related public spending on unemployment benefits increased in Spain.

During the boom period wages and prices increased faster in Spain than in the rest of the eurozone. Once the property bubble burst ${ }^{40}$ and the cajas were left with substantial bad loans, Spain entered into a recession. Increased production costs made Spanish outputs uncompetitive relative to other EU producers. In addition, capital not was invested in the production of tradable goods, but in buildings that remain vacant. The (new) technological capacity to respond to the new situation has been seriously weakened. A drop in domestic demand may not be compensated by increased exports elsewhere in the eurozone. The 'backward'

\footnotetext{
${ }^{38}$ Stratfor, 'Eurozone forecasts: Stormy with a chance of more bailouts', 11 November 2010.

${ }^{39}$ Portugal, Spain, Italy and Belgium all have rising costs financing their national debts. Crisis would spread like wildfire.

${ }^{40}$ Vacant properties stand at about a million. Their value depreciates, while the debt remains.
} 
Spanish products are competing against output from China and Eastern Europe. Unless serious restructuring takes place, Spain and other southern EU countries may never turn out to be the most favourable suppliers of such goods.

Without a national currency that can be manipulated (allowed to fall in order to make production competitive), Spain has the euro, which it does not control. The holders of euros do not have sufficient confidence in the Spanish Government's ability to collect enough taxes to repay bonds. They invest their euros elsewhere (Germany, Switzerland, Norway,...). The cost of borrowing for Spain has therefore increased. Growth-enhancing investments are suffering.

What are the policy options for Spain?

- Spain needs to go through an unpleasant and a rather unpopular and ugly process. It has to devalue. 'External' devaluation of the euro is out of the picture (this was not the case with the former peseta). Instead, Spain has to devalue 'internally': reduce wages, pensions and social expenditure, cut prices to have a competitive output and increase taxes. This can take years and provoke unemployment. If this lasts, it is a policy mix for bringing about social protests. The policy is also linked with the same volume of debt in euros, while incomes fall in the same currency. Slow and long-term recovery turns into concerns for the financial future. Countries with their own currency, such as Britain, Sweden, Japan or the US, borrow to cover deficits at relatively favourable rates. They may also print money and may see recovery much faster than Spain can expect.

- Spain may reschedule (prolong the payment) its debt hoping that a miracle may happen which would solve the debt crisis and other problems.

- The country may default on its debt. In this case it will not be able to get a new loan, especially not at a reasonable rate.

- Spain may hope that the common Eurobond would merge the risk and increase financial solidarity (fiscal transfers) within the eurozone. This is next to the last thing Germany would like to see. The German preference is for competitiveness and astute finances instead of Eurobonds.

There are no attractive or sweet options for Spain. Staying in the eurozone is linked to lengthy economic-recovery agony with slow growth, while leaving it would create financial crises, huge devaluation, inflation and potential sanctions by other EU countries (a devalued new peseta would strongly stimulate exports, which would jeopardise EU rules of competition, even stimulate a reintroduction of 
customs posts), while Spanish external debt in terms of euros would remain the same. A relatively swift return to 'normal business' is a far cry from reality.

\section{Italy ${ }^{41}$}

Italy has been a country with hopeless governance. Nonetheless, Italy predominantly has a confidence, not a solvency, problem inherited after decades of low and misguided investment, the short-sightedness of its leaders, low productivity and a declining industrial base. That Italy's problems are strongly linked to its (lack of) political leadership becomes evident from the swings in the yield gap between Italian and German bonds of different maturity, which have followed closely the 'personal' scandals of its ex-prime minister Berlusconi. An interesting study, which compared the borrowing costs of Spain and Italy (two countries that shared the same problems at the time the debt crisis emerged) with respect to the German bond yield, showed that Italy's performance compared to Spain worsened every time new scandals emerged. This has led to an increase in borrowing costs for Italy, compared to Spain, of the order of $€ 20$ billion. ${ }^{42}$

Italy has been facing a competitiveness problem, mostly linked to its financial and (family based, small) enterprise structure, which were part of the 'Italian miracle' of the 1960s, but left unreformed since, are currently impairing its transformation into a modern economy. Years of structural neglect have led Italy to lose some 40 per cent in labour competitiveness against Germany in the period 1995-2011, generating an overvalued currency locked in the eurozone.

The technocratic (not elected) government fronted by Mario Monti introduced reforms that moved Italy form the brink of default at the end of 2011. He also argued in favour of a substantial increase in the eurozone rescue fund. Additional unpopular and painful reforms are needed in Italy, especially in the labour market. Privileged workers have labour contracts that are virtually for life. Others, especially the young, have little job security.

Although markets and financial investors are putting all financially-affected European countries in the same basket, large differences exist among these countries that may require a different kind of inside order. Like Greece, Italy has been financially irresponsible for years, but in a different, Italian way:

- Italy has a budget deficit of 4.1 per cent of its GDP and has a primary budget surplus of 0.6 per cent, according to IMF 2011 statistics. The other European

\footnotetext{
${ }^{41}$ I am indebted to Lisa Borgatti for this section.

${ }^{42}$ T. Boeri, 'Italy's confidence crisis: Bad policies from bad politicians?', VoxEU.org, 17 August 2011.
} 
countries that do better are Norway and Switzerland.

- Italy has an average debt maturity of 7 years, which is longer than that of the other problematic countries in the eurozone and about half of it is owned by domestic investors.

- Its overall debt (public and private) is relatively low compared to other developed countries, due to the low level of private debt.

- As it was done in the past, Italy could also access other forms of wealth. Italy holds the fourth highest gold reserve in the world.

- Italy's net foreign liabilities are just one fifth of its GDP, compared to some 100 per cent of GDP for the other Southern and peripheral European countries.

In spite of attempts by a technocratic government to ease and, eventually, solve the Italian problem, the Italian economy is still close to the 'red zone' and may remain there for years.

\section{Muddling through Crises with no 'Resolution' in Sight}

Put in simple terms, the economy of the eurozone was operating 'smoothly' during the time when Germany, an export-based economy, was exporting while most other economies were importers, and while finance was available on favourable terms. Germany was Germany (exporter), because other countries in the eurozone had a different structure from Germany (importers). Weak domestic demand was solved by Germany through exports (financing exports). If the eurozone becomes an enlarged Germany, how can it operate in the long term? The worrisome thing is that there are no good answers to this question. ${ }^{43}$ How can the eurozone countries agree to go ahead? Is this the bright economic future promised to the citizens by the European elite when the eurozone was conceived and implemented? ${ }^{44}$

\footnotetext{
${ }^{43}$ When demand in the eurozone declined because of the crises, it is the domestic German demand and exports outside the eurozone and the EU that may compensate for that fall.

44، The EU's president told a selected audience of civil servants and businessmen that the Greek debt crisis and euro zone bailout had come as a nasty shock to ordinary Europeans. He said the public was not made aware of the full social and economic implications of the currency before it was created. "Nobody ever told the proverbial man in the street that sharing a single currency was not just about making peoples' lives easier when doing business or travelling abroad, but also about being directly affected by economic developments in the neighbouring countries," he said ... "Being in the 'Euro zone' means, monetarily speaking, being part of one 'Euroland'. "Vincenzo Scarpetta, an analyst for the pressure group, said: "The euro zone crisis is not simply about economic failure but also a breakdown in trust between the political class and European citizens. The EU elite simply got it wrong on the euro" (B. Waterfield, 'Ordinary people were misled over impact of the euro, says Herman Van Rompuy', The Telegraph, 26 May 2010).
} 
The European governments created the European Financial Stability Facility (EFSF) (€440 billion). It was established on 7 June 2010 in Luxembourg as a Luxembourg bank that would last for three years. ${ }^{45}$ This private bank can engage in any activity any other private bank can. So it may bailout a state. The rescue Facility requires neither action by the European Commission, nor the national parliaments, nor a unanimous vote among the heads of governments. It reports officially only to its board of directors. This is relevant as EU law forbids direct bailouts of a member state. The eurozone states do not provide the Facility with cash. They just guarantee a prearranged amount of assets that the rescue Facility holds, while the ECB provides (limited) loans to the eurozone banks as a part of its monetary policy. ${ }^{46}$ This rescue Facility may need to turn into a permanent eurozone economic instrument (fund). It ought to be based on:

- Strict conditionality

- Relatively low interest rates that ought to be passed on to borrowers (with a minimum service charge)

Germany has an awesome economic and political power. However, it is not omnipotent. Still, power also brings responsibility. The proposed new, tough eurozone structure is to the advantage of Germany:

- No country may devalue (to compete with German exports).

- All countries must be open to (German) goods and capital.

Would the 'poor' countries ever be able to develop and catch up with Germany? The eurozone's rules may turn into a formula for perpetual slump. The EFSF was established as an offshore bank that does not need EU approval. It is also chaired by a German (Klaus Regling) ${ }^{47}$ Its operation is based on a strict conditionality and low interest rates. Will this financial architecture hold the eurozone together or contribute to its downfall?

If the toughness in the implementation of the Pact prevails, then it would be far more difficult for the less developed eurozone countries to borrow, develop and compete with Germany. These countries with uncompetitive production structures would face years of stagnation. Asking these countries to approve of this situation would be like expecting sheep to vote for Easter. To solve this issue, a federal transfer of funds is necessary from the developed and prosperous countries to the poorer ones. How real is this? Germany is not enthusiastic about this idea at all.

\footnotetext{
${ }^{45}$ The ECB acts as agent of the EFSF in financial markets from January 2012.

${ }^{46}$ Stratfor, 'German designs for Europe's economic future', 4 November 2010.

${ }^{47}$ Stratfor, 'Remaking the eurozone in a German image', 19 October 2010.
} 
At the October 2010 EU summit, Germany pushed through the agreement that the future eurozone rescue and debt-restructuring packages should include an orderly sovereign debt default. Investors must bear certain losses ('haircut') for their imprudent (hazardous) investment behaviour. This is reasonable in the existing eurozone structure, otherwise bond investors have no reason to distinguish between good and bad government bonds and credit ratings ${ }^{48}$ of different countries. The investors buy treasury bonds that have high interest rates (gamble) knowing that the country in trouble will be bailed out. Hence, investment decisions send distorting signals throughout the economy. They invest in unsafe bonds neglecting related risks as a bailout is guaranteed because of the eurozone's solidarity. Such hazardous investors should not be permitted to endlessly take taxpayers as hostages. Sovereign default must be a credible threat as a 'tax' that represents a 'haircut' on hazardous investment.

To codify a sovereign debt default mechanism ('haircut') in the Treaty 'is a very bad decision that will make the eurozone more fragile by making financial crises an endemic feature of the Eurozone.... the proposed sovereign debt default mechanism is based on a wrong diagnosis of the causes of the debt crisis in the eurozone' (de Grauwe, 2010, p. 1). This prognosis is based on the assumption that the crisis is based on the reckless spending behaviour of the governments that relied on implicit bailout guarantees. At the same time, private investors did not care to restrain these prodigal governments. While this scenario may explain the situation in Greece, it is unbecoming when the root of the debt problem is in the private sector. Following the Global Credit Crunch, the accumulated private debt and the recession-related decline in public revenue 'obliged' the eurozone governments to step in and increase their debt, which soared. 'This increase was necessary to save large segments of the private sector. It had nothing to do with irresponsible governments that failed to be disciplined by financial markets. The reverse is the truth. Financial markets were undisciplined and governments took their responsibility when they saved them' (de Grauwe, 2010, p. 2).

If the Treaty-enshrined mechanism to deal with sovereign debt default implies a 'haircut', investors will increase interest rates on these risky bonds. At the time of crises (payment difficulties encountered by some governments), investors/

\footnotetext{
${ }^{48} \mathrm{~A}$ credit rating is similar to film critique. It is subjective and often misleading. A close relation with a popular actor or film producer may increase the visibility or profile of the critic over a short period of time, but this undermines objectivity, especially in the long term. Credit rating agencies give a high rating to rotten financial and other firms just before their bankruptcy. Moreover, a lower rating may mean that a borrower ought to pay a higher interest to compensate for the default risk.
} 
speculators will sell these bonds, making it harder/even more expensive for the government in question to both to get money on the capital market and to service its debt. The new funding architecture ought to have some reference to a sovereign default/debt restructuring and a link to private investors. These investors must know outright that future bailouts will be neither automatic, nor unconditional, nor made in full. Switzerland offers a good example to follow in this regard. Private investors must have a warning signal in advance that there is a potential 'haircut' on their hazardous investments. Otherwise, market signals relating to prudent national economic behaviour and to behaviour that is not will be distorted, while speculation will increase. In the end, taxpayers will be endlessly burdened with unwanted debt. In this case, German taxpayers and some from other countries may easily say: 'enough is enough!'.

A solution to the problem is proposed by de Grauwe (2010, p. 3):

The sovereign debt default mechanism, if implemented, will lead the eurozone governments to downgrade their own sovereign debt. There is no surer path to self-destruction...Financial solidarity is deemed politically unacceptable in a number of countries. The truth, however, is that a monetary union can only survive if there is a willingness to provide mutual financial assistance in times of crisis. No monetary union can survive without such solidarity mechanism. The solution therefore is not to implement the sovereign debt default mechanism, which will lead to the demise of the eurozone, but to give a permanent character to the European Financial Stability Facility, or better to transform it into a European Monetary Fund.

If the crisis spreads, another global recession is inevitable. Important messages were therefore communicated. The German Chancellor, Angela Merkel, stated that 'if the euro fails, then Europe fails. ${ }^{49}$ European Council President, Herman van Rompuy, said: 'If the euro did not survive, neither would the EU'. ${ }^{50} \mathrm{EU}$ partners need to increase their confidence and in their common project, otherwise it is not only the common currency that may disappear, but also internal free trade, the Common Agricultural Policy and political cohesion.

At the 16 December 2010 summit, the leaders agreed to amend the Lisbon

\footnotetext{
${ }^{49} \mathrm{~T}$. Garton Ash, 'Calling Germany, calling Germany: you alone can keep this eurozone show on the road', The Guardian, 24 November 2010.

${ }^{50}$ The Economist, 'A contagious Irish disease?', 25 November 2010.
} 
Treaty. This was a reaction to the markets' rather poor pre-crisis record in disciplining countries with a lax fiscal policy. The two-line amendment to create a permanent liquidity facility (European Stability Mechanism [ESM]) from 2013 reads: 'The member states whose currency is the euro may establish a stability mechanism to be activated if indispensable to safeguard the stability of the euro area as a whole. The granting of any required financial assistance under the mechanism will be made subject to strict conditionality. ${ }^{51}$ The ESM, with its financial 'firepower' of $€ 500$ billion (paid in capital), would replace the EFSF (based on national guarantees) when it expires in 2013. Even though this fund may seem substantial, its volume is meant to deal with the problems of small eurozone countries. The ESM is far from sufficiently large to rescue a big eurozone country such as Italy or Spain. Therefore, a political, fiscal and transfer union may be one solution if the countries are serious about the euro and want to keep the eurozone.

If a eurozone country behaves badly, the ESM is there to provide a life boat. The potential debt problem is understood to be a possible series of individual country problems, not the systemic problem of the eurozone felt throughout the group (de Grauwe, 2011, p. 20). The strict borrowing rules from the ESM would request sharp austerity measures. Tightening the national belt to reduce budget deficit would make the crises even more severe because of high interest rates and deflation. Too much emphasis on punishments in the new eurozone and too little on solidarity, coordination and growth is not an encouraging sign for its long-term viability.

The Franco-German (2011) proposed plan called the Competitiveness Pact (Pact for the Euro or the Euro-Plus Pact) links the bailout funds to a closer integration in the eurozone, i.e, tough fiscal measures, as well as reforms that would increase competitiveness. It also includes the scrapping of the indexation of wages/pensions, a common base for corporate taxes, nationally supervised constitutional debt limits and raising the retirement age to 67 .

Following a set of unprecedented and marathon eurozone crisis summits in October 2011, French president Sarkozy said that it had been 'an error to allow Greece to join the euro a decade ago. ... If the euro had exploded... all of Europe would have exploded'. ${ }^{52}$ The new bailout deal to help Greece included a $€ 130$ billion loan from the EU and the IMF, for private investors a 50 per cent cut in the

\footnotetext{
${ }^{51}$ European Council, Conclusions, Brussels, 16-17 December 2010, Decision No. 3.

${ }^{52}$ L. Elliott, J. Treanor and H. Smith, 'Eurozone crisis: Sarkozy says Greece was not ready to join euro', The Guardian, 27 October 2011.
} 
face value of the bonds and an intention to increase in 'firepower' of the EFSF to $€ 1,000$ billion (with an eye on countries such as Italy and Spain). From where would the money come to stuff this fund? Fundraising would rely, in part, on China. It is peculiar that the rescue of the free market economies may come from communist China, a country in which the employed are paid less than the equivalent unemployment benefits in the EU. China is also a country which has a lower credit rating that the EU countries that it is rescuing. ${ }^{53}$ Some rescue funds would also come from Russia. The world has changed, indeed.

France and Germany drafted and circulated new rules before the 9 December 2011 summit. The EU integration initiative was seized by the governments. The European Commission, the guardian of the EU's interests, was a bystander. The community method of guiding the EU was again replaced by intergovernmental agreement.

A possible failure of the eurozone has been alarming and horrifying for politicians. A new Fiscal Compact ${ }^{54}$ was 'agreed' on 9 December 2011 among eurozone members and other EU countries bar Britain. Britain wanted to protect the liberal financial rules and the City of London, while the other countries (principally France) argued that the liberal financial rules were the cause of the troubles. The lightly regulated City does business all over the world because of its favourable geographical location. It is in a time zone that permits business with both Asia and New York during the same day. The City does not want to be bound by EU regulations from Brussels as most of its business is outside of Europe. Also, the City specialises in wholesale finance, while EU influence and regulation may be in the retail business and the protection of small investors and 'widows'. Such regulation may be inappropriate and costly for those that deal with large institutions. As the pan-EU deal was blocked by Britain, the 26 countries pursued the path of an intergovernmental accord. ${ }^{55}$ The intention of the deal is to create a genuine 'fiscal stability union' in the euro area. The commitment is to new fiscal rules which contain core elements such as:

- General government budgets shall be balanced or in surplus. An annual deficit of up to 0.5 per cent of the nominal GDP is tolerated. This may be a kernel of

\footnotetext{
${ }^{53}$ China may be much more interested in buying assets such as infrastructure and factories in the EU than in eurozone bonds the prices of which may fall or turn in 'confetti'.

${ }^{54}$ European Council, 'Statement by the euro area Heads of State or Government', Brussels, 9 December 2011.

${ }^{55}$ As Britain is outside this fiscal agreement, France and Germany intend to carry on without Britain in other areas such as a common corporate tax base and labour laws.
} 
the emerging fiscal union.

- The above rule will be introduced in member states' legal systems at constitutional or equivalent level. The European Court of Justice would verify this transposition.

- Member states that have excessive deficits shall submit for 'endorsement' an 'economic partnership programme' to the European Commission and the European Council. The programme shall include economic policy and reform measures to correct excessive deficits. Annual implementation of the programme shall be monitored by the Commission and the Council.

- An ex ante mechanism will report on the member countries' debt plans. If a deficit is out of step with the Stability and Growth Pact, the European Commission will request a revision of the national budget. Cooperation with Brussels on those matters is, in fact, coercion. National governments would become puppets of the European Commission.

- If the deficit breaches the 3 per cent GDP ceiling, 'there will be automatic consequences unless a qualified majority of euro area Member States is opposed'. These automatic consequences are presumably sanctions (fines, cuts in the receipt of the EU funds,...). So the unelected technocrats from the European Commission would impose sanctions on elected governments. The same European Commission has not obtained a 'clean bill of health' on its expenditure from the Court of Auditors since 1994.

- National debt should be reduced by $1 / 20$ a year of the difference between the current debt and 60 per cent of the GDP, norm prescribed by the Stability and Growth Pact.

No matter what the final legal wording of the deal to be translated into national constitutions will be, the substance of the main provision is clear: countries will have to give a part of the national budgetary power to 'Brussels' based on a strong German template. The governments deny themselves the chance to stimulate demand and growth in times of stagnancy or recession. They are locked in austerity and deflation. Only the Treaty change may provide the grounds for the involvement of the European Court of Justice in these matters. Many EU countries will have a long, bitter and uncertain struggle to ratify the change, which deals with the most profound dimension of national sovereignty. In some cases (Ireland) this may call for national referendums, even their replays. The Czech Republic and Britain abstained from the provisional signing of the new European Treaty on 30 
January 2012. Britain argued that this was a treaty outside the EU. How does this factor in the EU's effectiveness and influence?

For a long time the EU country leaders were able to agree on very few things, especially big ones. The level of acrimony is rather strong in the EU. Still, the agreement on something, no matter how imperfect, is a sign of a certain commitment to put a patch on the leaking bucket.

The Fiscal Compact is based on a strict German template. An 'agreement' is found, but not the solution to the eurozone problems. Some countries will need to have a national referendum on this deal. The new rules shall have a strong deflationary impact on the economy. In addition, the member states lose a big part of their ability to run independent fiscal policy. They have to ask other countries (principally Germany) how much they can tax, spend and borrow each year. The most draconian of the new measures is the $1 / 20$ rule. If applied to the letter, the eurozone states, especially the ones in trouble, face a decade of austerity, prolonged depression, little or no growth and social unrest. In addition, fiscal sovereignty evaporated. It is hard to envisage how this new financial arrangement and 'indefinite' austerity is going to endure the test of national politics. The omens are not good.

Germany was first paying war reparations, then for the economic healing of the former East Germany, and later for the rehabilitation of the Eastern European countries. Now Germany has had enough. A new 'transfer union' is not on the German agenda. Why should Germany accept this without the control of other partners' expenditure? Germany is therefore in favour of the strong, effective and enforceable control of national budgets and 'internal devaluation'. If this happens, the nature of the EU would change beyond recognition. Everything would be subject to the euro.

German financial sovereignty was reinforced by the ruling of the German Constitutional Court (September 2011). The German parliamentary budget committee must approve in advance all German guarantees to new loans in the eurozone. The ruling is clear: there are no permanent, open-ended and unlimited new rescue mechanisms for eurozone partners. Such authorisations may complicate the management and resolution of eurozone crises in the future.

German financial oxygen given to those with financial wheezes may well be offered with Teutonic clarity and conditions. If German patience and its rather limited tolerance run out, the financial oxygen may turn into something else. The European integration project may be cracking on the issue that it was supposed to 
resolve, i.e., solidarity and nationalism.

It is very difficult and time consuming to restore growth and recovery with a strong currency. National fiscal power was also moved from the elected national parliaments to the unelected technocrats in Brussels. Could this bring the EU to a new fundamental crisis? Or to an outcome different from those that are intended? Too much austerity based on the German template may provoke anti-German feeling that may not lie too deep under the surface. ${ }^{56}$ This is the exact opposite to the ideal upon which the EU was founded.

Monetary policy is fully in the hands of the EU institutions. If voters cannot influence national revenue and expenditure, what exactly is there to vote for? Who controls money and the budget controls the whole country. What remains of national sovereignty? It is peculiar that ideas such as this, that dent the notion of democracy, are bubbling up in Europe. It is hard to translate these legal, political and economic assertions and commitments in plain language, understandable to the people in the street, without lying in order to win support and votes. This arrangement will bring sustained austerity more than it will bring growth. Without growth, there will be even more austerity.

There are several obvious lessons learned from the Great Depression. One is that governments should not try to balance budgets when there is a collapse in economic activity. Another is that central banks must be ready to provide ample liquidity. ${ }^{57}$ In addition, the exchange rate ought to be accommodating (fluctuating) to assist in restoring competitiveness. George Santayana (1863-1952) said 'when experience is not retained, as among savages, infancy is perpetual'.

The EU law rules out large bond purchases by the ECB. However, the ECB agreed in December 2011 to provide unlimited loans to commercial banks for up to three years at its main rate of interest ( 1 per cent).$^{58}$ As soon as this new lending arrangement appeared as an option, over 500 European banks borrowed $€ 498$ billion from the ECB, twice as much as was anticipated. These funds may be used by the banks to buy EU governments' bonds because many of them cannot raise funds at open market at a reasonable rate. At least this was the intention. Banks

\footnotetext{
${ }^{56}$ Greece, for instance, lost its sovereignty to many occupiers. There were the Romans, the Turks and the Nazis. The brutal Nazi occupation is in the living memory of the Greeks. Not only were tens of thousands Athenians killed, but hundreds of thousands died of starvation.

${ }^{57} \mathrm{P}$. de Grauwe, 'Ominous lessons of the 1930s for Europe', Financial Times, 17 January 2010.

${ }^{58}$ The Economist, 'The euro crises? Damned with faint plains', 17 December 2011.

${ }^{59}$ L. Elliott, 'Banks snap up $€ 500 \mathrm{bn}$ in loans from European Central Bank', The Guardian, 21 December 2011.
} 
thought that instead of propping up their own governments a safer investment bet would be US government bonds. ${ }^{59}$

The eastern EU member countries won their liberty from the Soviet Union to determine and handle their affairs without foreign influence, free from the meddling in their national affairs performed by the unelected communist technocrats in Moscow. The new eurozone rules may look like a medieval torture chamber: to be shown to the countries in order that they never be used. The threat would be that a sovereign nation has to pass on its economic policy to the European Commission (unelected technocrats that have no public to answer to directly and are responsible only to their colleagues and superiors). The question is whether this would be acceptable enough to the German Constitutional Court. Another question is if, and how, this would relate to the fundamental principle of equal treatment for all EU countries under EU law. The eurozone's top officials may call this all stabilisation. Others may call it differently.

A common eurobond would be a strong symbol of a vision and promise of a collective future and solidarity with discipline, but it would not solve the problem of the creditworthiness of each individual member country. Sharing risk and a future with other eurozone countries that have a record of fiscal delinquency would increase interest rates to Germany, hence it is a political non-starter. Collectivisation of the debt and footing the bill of other fiscal wrongdoers is not a palatable proposition to German taxpayers, who refuse an endless commitment. However, the strong resistance shown by the taxpayers is not the only problem. Another is that German 'financial firepower' is not without bottom.

If investors get the message that eurozone longevity is unrealistic, they may bet on its break up revealing a hard Germany-based core and a soft fringe.$^{60}$ What kind of message will be sent to the Czech Republic, Poland, Romania and others that may strive to join the eurozone? In some specific cases, such as in the US, the longer a monetary union lasts, the stronger the chance that it will survive. ${ }^{61}$ Therefore, political and organisational innovations may be necessary along federal lines, i.e., the creation of a eurozone body that is in charge of both monetary and fiscal matters. This may be quite difficult as national finances (taxes and

\footnotetext{
${ }^{60}$ There could be two distinct eurobonds: hard and soft. The soft one may bring higher interest rate than the hard (German) one, but the soft one would be also a riskier investment.

${ }^{61}$ Hurricane Katrina in 2005 had a strong negative shock on the economy of the State of Louisiana. 'The State of Louisiana did not contemplate abandoning the dollar and introducing its own currency, even though a sharp depreciation might have been appropriate for addressing some of its economic problems' (B. Eichengreen, 2007, p. 37).
} 
expenditure) are at the heart of parliamentary democracies and national sovereignty. Many eurozone countries argue that the countries themselves should be responsible for their own prudent finance and that they should not be supervised and guided by external bodies.

A new, EU proposed, 0.1 per cent tax on financial transactions could raise about $€ 55$ billion a year. ${ }^{62}$ This 'Tobin tax' is quite divisive. While Germany and France support it, Britain is staunchly against it. This tax would be a disaster for the British financial services industry. Britain is the country with the biggest financial services industry in the EU (almost three quarters of the EU total). As such, Britain would pay most of these tax proceeds to the EU budget, while contributing only a tiny proportion of what is necessary to rescue the euro. Sweden implemented a similar tax in 1980s. The result was that the government collected only a small part of the expected revenue, while much of the country's financial business moved abroad. The banks passed on the tax burden to the clients through higher fees. ${ }^{63}$ Such a transactions tax could make sense if it were applied globally. Otherwise, the financial business in London would escape to the Far East and New York.

Even though it has a profound impact on the European economy, the eurozone is still a predominantly political project. Fiscal and political union are still missing to underpin this Euro-federal project. Federalists, strongly supported by banks with investments in debtor countries, will fight tooth and nail to avoid eurozone disintegration. The problem is the 'federal' rescue fund would require a serious change in the EU treaties.

The eurozone's original design was imposed by the elite on very reluctant people and voters. The elite regarded possible crises as a 'technical matter' that could be solved within the existing EU framework. The monetary union was created without the indispensable institutions and rules that are now applied to support the operation of the eurozone (fiscal surveillance, coordination and transfers). The original eurozone design has failed.

There are a lot of adolescent troubles for the eurozone to overcome before it can reach maturity and its $20^{\text {th }}$ anniversary. If given proper direction and if they have suitable rigour, youngsters can develop into prosperous people to the benefit of everyone. The eurozone needs adjustment and continuous care. The eurozone has its costs, but the potential long-term benefits are also enormous. The most crucial

\footnotetext{
${ }^{62} \mathrm{~N}$. Clark, 'Treasury vows to oppose Barroso's plan for Tobin tax', The Independent, 29 September 2011.

${ }^{63} \mathrm{~K}$. Sigfrid, 'Leave us out of the EU tax experiment', The Telegraph, 16 February 2012.
} 
thing for the success of the eurozone is that participants see it as a beneficial deal. If such an observation evaporates, so too will the political glue that holds the eurozone together. The eurozone ought to move forward toward a form of fiscal integration; otherwise it will go backwards. In either case it is a choice to be made by the people and politicians, involving their perception of a common future. European monetary integration is predominantly a political process which may not be predicted by economists. The eurozone is a grand project. To succeed in the long term, the project asks for strong solidarity, including financial solidarity among its governments and people. However, this solidarity is in rather short supply.

\section{Conclusions}

The eurozone and its currency, the euro, is a great federalist project. No single currency has circulated so widely in Europe since the Roman Empire. The eurozone and the euro were the shining crown jewels in the EU integration process, as it took place in a voluntary way during a time of peace. Paradoxically, they are its weakest links. The monetary union succeeded, but the economic union which brings long-term prosperity and growth is yet to come. Compared to the preceding situation, a monetary union replaces currency exchange risk with a credit risk. If national governments spend excessively, the depreciation of the exchange rate of the national currency is replaced by increases in the rate of interest on national government bonds.

By entering into a monetary union with Germany, France intended to 'lock' (and to control as much as possible) the unified Germany firmly in the European project for a long period of time. The crucial part of the economic policy (money) was expected to be managed jointly and to happily benefit all in the EU. And it was so for some time. Two decades after the Maastricht Treaty the opposite took place: the common money strongly assisted German exporters and it put Germany in the driver's seat of the eurozone and the EU.

France has had a number of original plans to control and/or be in partnership with Germany since the Second World War. What can happen if the 'monetary cage' breaks up and Germany goes on its own and seek partners elsewhere (Russia) in the longer term? What would happen to the French economy if the 'monetary cage' holds and French economic policy is constrained by German economic policy? A rather modest social and financial change in the retirement age 
from 60 to 62 years in France provoked strong and decisive protests in France in October 2010. France and Germany need each other to lead Europe; they may not be able to do that on their own. Each of them needs a partner for this important and responsible job. If the economies of these two countries diverge in the future, would Germany wish to keep France as a partner in the long term? This decision will be made in Berlin.

The eurozone brought and kept stability of prices. It assisted in weathering the storm of the Global Financial Crises and their aftermath. The stability of a currency is not the sign of its underpinning economic potency. The potency of a currency is epitomised in economic growth, reformed production structure, increased productivity and continuous adjustment to economic challenges and opportunities. However, this virility and growth part of the promise to the citizens has not yet been realised by the eurozone. There will be little growth unless there is a stronger increase in productivity. This is linked with reform (especially in the southern countries) in the labour market, the need to educate labour forces to bring about new opportunities, and to invest in new and highly productive technologies in the light of both an ageing population in Europe and competition from Asia. Countries with strong economies, such as Germany, ought to increase consumption, especially of goods and services offered by the southern countries.

From a global perspective, the euro is still only a regional currency with an uncertain future. If the EU does not reinvigorate its production potential, and reach and apply a consensus about its economic and political future, it may therefore be caught between the US and China and slide into oblivion like the once mighty Venetian Republic. During the times of the communist threat, integration was in part a European necessity. Following the demise of that threat, European integration turned more strongly into national choice. The global economic powerhouse is moving towards the Pacific. A possible future clash between the US and Asia, may again turn European integration into a necessity.

The choice for the eurozone is, first, to have weakly applied eurozone rules in a dysfunctional monetary union, or, second, to go for a stronger fiscal, economic and political union. As long as the national governments are sovereign and the EU lacks a political union, the eurozone has the potential for disintegration. Third, as long as countries are sovereign, monetary unions cannot be regarded as irreversible projects. Many earlier monetary unions disintegrated either violently (AustriaHungary in 1918, Yugoslavia in 1991) or peacefully (the Latin Monetary Union in 1927, Britain-Ireland in 1979, the Soviet Union in 1991, Czechoslovakia in 1993). 
If a monetary union is unsustainable and its operation is very problematic, it will not last forever. In the case of monetary breakup, the experience of the former Yugoslavia showed that the first to leave incurs the smallest damage.

Political statements are not the foundations that determine the ultimate faith (good or bad) of a currency. The reality is that all fiat currencies fail at some point. Europe has a long and rich history in these matters. Those fiat currencies that have held the longest (so far) are the Swiss franc, US dollar and the British pound.

Martin Luther wrote his Ninety Five Thesis in Wittenberg, in 1517, against the profligacy of the Catholic Church, especially against the sale of indulgencies. Another German (Angela Merkel) wrote her thesis for the new eurozone rules and nailed that down in Brussels on 9 December 2011. Germany put a price on involvement in the eurozone rescue packages and continued involvement in the EU. The price is that integration may continue, but on German terms. Germany, now alone at the controls of the European integration cockpit, wants to preserve the euro and the EU, but in a way that does not damage the German economy and its taxpayers. The basic problem is the misdiagnosis of the crisis. It is not caused by the feeble and sloppy enforcement of the rules, but rather by the fundamentally flawed model on which the eurozone was constructed.

Coming back to the title of this article, we would argue that so much political and economic capital was invested in this project that it will need to go on (at least for a while). This invested capital is reinforced by the pressure from the market, which may persuade countries to compromise. So far the eurozone, especially Germany, were ahead of the markets as several eurozone countries were (temporarily) rescued. The issue is, however, the size and composition of the eurozone at its $20^{\text {th }}$ birthday. Will it enlarge to include new members, if not will the composition of the existing number of members be the same? Will Belgium split and will the two new countries separately join the eurozone? Will Iceland and Croatia join the eurozone? The time length until the $20^{\text {th }}$ eurozone anniversary (2019) is a very, very long period in politics. Lest it be forgotten that Germany (still) benefits enormously from the eurozone and that it would not easily let it collapse.

With too much debt and without the possibility to devalue, slow growth countries should aim for structural reforms that can reduce domestic labour costs, stimulate competition and entrepreneurship, introduce new technologies, while keeping their goals to regain the competitiveness of their output and economic growth. The only strategy so far implemented by national governments and 
eurozone leaders has been to oversee a chain of rescues of the eurozone's member countries. Eurozone sceptics would ask: 'Is this similar to a rearrangement of the deckchairs on the Titanic? Should these leaders not turn their attention and funds towards longer term and more fundamental issues such as the stimulation of growth, rather than the stability of the euro?' The real side of the economy (growth, jobs, output) matters in reality more than the nominal indicators (inflation, budget deficit).

Higher growth has always been the best way out the debt (absolute and relative) burden. However, growth prospects for the near and medium-term future are quite weak. Growth will not come without an increase in consumption, but increased consumption will be hard to achieve with banks that are constrained or wary of lending.

The euro was supposed and expected to foster economic and other sociopolitical convergence in the eurozone. However, it created divergence. The single European market was the engine of the EU's economic growth, not the euro. Do the leaders have the capacity and will to look beyond the fixing of the 'leaking pipes' (rescues) and to turn to growth? This would be the strongest real eurozone confidence-building tool.

The laws of economics, like the law of gravity (can water flow freely uphill?), do not abide by political promises, ideas and checks. Political lobbying and bullying does not bear fruit easily with markets. It remains to be seen if the might of the financial market is going to be stronger than the political promise, government purse and will of the statesmen in order to avoid the slow motion eurozone train crash.

During the Great Depression, Heinrich Brüning, the German Chancellor (193032 ), thought that a strong currency and a balanced budget were the ways out of crisis. Cruel austerity measures such as cuts in wages, pensions and social benefits followed. Over the years crises deepened. This led to what the reader of this article knows. ${ }^{64}$ Once the financial and the existential storm is over and new EU architecture is in place based on the tough German template, a number of EU countries may not like or enjoy the EU that they live in. Many of them may find themselves in the slow-lane of European integration. The EU will not be the same again. It is turning into a multi-speed and multi-directional EU.

\footnotetext{
${ }^{64}$ The stringent euro template acts as the gold standard. If the template survives without changes (easing), the fear is that the economic costs may be calculated not in terms of money, but rather in terms of dead bodies.
} 
Many thought that a common currency was unthinkable in Europe some three decades ago. It arrived. Many think that political and fiscal unions are impossible now. Political will and commitment (if they exist) may prove them wrong and may avoid turning Maastricht into Arnhem. No matter how the eurozone crisis ends, it will not be glorious. The final message from this article is that, in spite of gloom and doom, it brings hesitant optimism about the future of the eurozone, with an emphasis on 'hesitant'. ${ }^{65}$

\section{Acknowledgement}

This article is based on my presentation 'Stumbling blocks on the Eurozone's road towards its $20^{\text {th }}$ anniversary' presented at the conference '1999-2009 Ten Years of the Euro: Experiences and Prospects of EMU and ECB Monetary Policies' held at the University of Genoa on 28 October 2009. I have benefited from discussions with many friends and colleagues, but I owe a special debt of gratitude to Lisa Borgatti, Eric Fiechter, Christos Gortsos, Isidora Ljumović, Franco Praussello and Jele Tosun. The views expressed are my own and do not necessarily reflect the position of the organisations for which I work. I am solely responsible for all errors and mistakes.

Received 3 December 2010, Revised 5 January 2012, Accepted 10 January 2012

\section{References}

Baldwin, P. (2006), 'The Euro's trade effects', European Central Bank, Working Paper No. 594.

Bordo, M., and L. Jonung.(1999), 'The future of the EMU: what does the history of monetary unions tell us?, NBER Working Paper, No. 7365.

Buiter, W. (2006), 'The sense and nonsense of Maastricht revisited: what have we learnt about stabilization in EMU?', Journal of Common Market Studies, pp. 687-710.

Buiter, W., and E. Rahbari. (2010), 'Greece and the fiscal crisis in the eurozone', CEPR

\footnotetext{
${ }^{65}$ Applying purely economic analysis and theory Jovanović (1997, p. 68) was strongly in favour of monetary integration in the EU, however he was quite sceptical about its structure and actual implementation in the future as set in the Maastricht Treaty (1992). He argued in favour of the postponement of the implementation of the eurozone. The EMU was missing from the outset other necessary federal elements for long-term operational success: automatic stabilisers, eurozone bonds, rescue funds, fiscal transfers and strong fiscal coordination. Jovanović was wrong because he underrated at that time the strongest political commitment and determination to implement the EMU as it was set by the politicians in Maastricht. Is Jovanovi ć this time overrating the EU leaders' political commitment, will and funds?
} 
Policy Insight, No. 51.

de Grauwe, P. (2003), Economics of Monetary Union. Oxford: Oxford University Press. de Grauwe, P., and G. Kouretas (2004), 'Editorial: EMU current state and future prospects', Journal of Common Market Studies, pp. 679-687.

de Grauwe, P. (2006), 'What have we learnt about monetary integration since the Maastricht Treaty?', Journal of Common Market Studies, pp. 711-730.

de Grauwe, P. (2010), 'A mechanism of self-destruction of the eurozone', CEPS Commentary, 9 November 2010.

de Grauwe, P. (2011), 'A fragile eurozone in search of a better govermance', CESifo Working Paper, No. 3456.

dellas, H., and G. Tavlas. (2009), 'An optimum-currency-area-odyssey', Bank of Greece, Working Paper No. 102.

Eichengreen, B. (2007), 'The breakup of the euro area', NBER Working Paper 13393.

Eichengreen, B. (2008), 'Sui generis EMU', NBER Working Paper 13740.

Feld, L.P. and J.G. Matsusaka. (2003), 'Budget referendums and government spending: evidence from Swiss cantons', Journal of Public Economics, pp. 2703-2724.

The International Economy. (2010), 'The Euro: will it still be around five years from now?' (A symposium of views), Spring.

Jovanović, M. (1997), European Economic Integration: Limits and Prospects. London: Routledge.

Jovanović, M. (2006), The Economics of International Integration. Cheltenham: Edward Elgar.

McKinnon, R. (2004), 'Optimum currency areas and key currencies: Mundell I versus Mundell II', Journal of Common Market Studies, pp. 689-715.

Melitz, J. (2004), 'Risk-sharing and EMU', Journal of Common Market Studies, pp. 815840.

Pitelis, C. (2012), 'On PIGS, GAFFs and BRICs: An insider-outsider's perspective on the structural and industrial foundations of the Greek crisis', Judge Business School, University of Cambridge, mimeo.

Praussello, F. (2011), 'Asymmetric shocks and monetary disintegration: the case of the eurozone', in International Handbook on the Economics of Integration: Competition, Spatial Location of Economic Activity and Financial Issues (ed. M. Jovanović). Cheltenham: Edward Elgar, pp. 360-377.

Santos Silva, J., and S. Tenereyro. (2010), 'Currency unions in prospect and retrospect', Annual Review of Economics, pp. 51-74.

Wickens, M. (2007), 'Is the euro sustainable?', CEPR Discussion Paper No. 6337. 